Portland State University

PDXScholar

5-10-1988

\title{
The Mechanism of Intrusion of the Inyo Dike, Long Valley Caldera, California
}

Ze'ev Reches

Hebrew University of Jerusalem

Jonathan H. Fink

Portland State University, jon.fink@pdx.edu

Follow this and additional works at: https://pdxscholar.library.pdx.edu/geology_fac

Part of the Geology Commons, and the Volcanology Commons

Let us know how access to this document benefits you.

\section{Citation Details}

Reches, Z. E., \& Fink, J. (1988). The mechanism of intrusion of the Inyo dike, Long Valley Caldera, California. Journal of Geophysical Research: Solid Earth (1978-2012), 93(B5), 4321-4334.

This Article is brought to you for free and open access. It has been accepted for inclusion in Geology Faculty Publications and Presentations by an authorized administrator of PDXScholar. Please contact us if we can make this document more accessible: pdxscholar@pdx.edu. 


\title{
The Mechanism of Intrusion of the Inyo Dike, Long Valley Caldera, California
}

\author{
ZE'EV RECHES \\ Geology Department, Hebrew University, Jerusalem, Israel
}

JONATHAN FINK

Geology Department, Arizona State University, Tempe

\begin{abstract}
We analyze the intrusion of the 11-km-long Inyo Dike at the margins of Long Valley caldera, eastern California. The dike trends $\mathrm{N}^{\circ} 7^{\circ} \mathrm{W}$ and is divided into at least three segments which are rotated by as much as $25^{\circ}$ with respect to the main trend. The dike seems affected primarily by the regional stress field of right-lateral shear of the western United States and by the local thermal conditions of the crust; the dike seems unaffected by the preexisting caldera margins and Sierra-Nevada frontal fault system. The high heat flow in Long Valley caldera implies that crustal rocks below $3-4.5 \mathrm{~km}$ deform by steady state creep under tectonic strain rate and support low to vanishing tectonic shear stresses. The upper rocks, above $3-4.5 \mathrm{~km}$, deform by frictional slip along fractures and may support tectonic shear stresses as high as $24 \mathrm{MPa}$. We demonstrate that depth variations of tectonic stresses may have a profound effect on the segmentation and rotation of dikes, both at Long Valley and in other areas of high heat flow. The analysis places constraints on several tectonic conditions. The Inyo Dike intruded under a tectonic stress state with a horizontal maximum compression oriented $\mathrm{N}^{\circ} 7^{\circ} \mathrm{W}$. The maximum extensional fracture strength of the host rocks is $1-2.5 \mathrm{MPa}$, and the pressure drop within the propagating Inyo Dike was about $0.55 \mathrm{MPa} / \mathrm{km}$. The volatile overpressure in the magma chamber was about $15 \mathrm{MPa}$ during eruption of rhyolitic lavas at the Inyo Domes.
\end{abstract}

\section{INTRODUCTION}

Seismic activity and ground deformation since 1980 have focused attention on Long Valley caldera as a site of incipient volcanic activity. The last major volcanic event to occur in this area was the emplacement of the Inyo Domes and associated pyroclastic deposits approximately 550 years ago; these features were fed by an 11$\mathrm{km}$-long dike we will refer to as the Inyo Dike. The distribution of Holocene vents in Long Valley suggests that future eruptions will likely be fed by pipes situated along dikes.

The Inyo Dike provides a good opportunity to analyze the process of magma propagation from source area to the surface, thanks to detailed studies of the region. The three-dimensional geometry of the dike has been resolved on the basis of surface structural features and mapping of the domes [Fink and Pollard, 1983; Fink, 1985; Mastin and Pollard, in press]. Three research drill holes at the Inyo Domes provide subsurface control on the dike geometry and its composition [Eichelberger et al., 1985]. The vast body of geophysical measurements in Long Valley caldera further constrains the mechanical and rheological conditions of the upper crustal rocks here [e.g., Hill et al., 1985].

In this paper we explain the dike geometry in terms of the interaction between tectonic stresses and local variations in host rock rheology. We evaluate relationships between tectonic and magmatic stresses and estimate the magnitude of magmatic pressure at depth necessary to get the dike to the surface. Application of the model to other volcanoes is also discussed.

\section{The Inyo Volcanic Chain}

Based on mapping and age dating of pyroclastic deposits and silicic extrusions in the western part of Long Valley caldera, Miller [1985] proposed that the three largest Inyo Domes and the adjacent

Copyright 1988 by the American Geophysical Union.

Paper number 7B7019.

0148-0227/88/007B-7019\$05.00
Inyo Craters were fed by a single 11-km-long, north trending dike (Figure 1). Fink [1985] mapped ground cracks, normal faults, and phreatic pits on and around the domes and concluded that they were fed by a N-S trending dike that divided into at least three NNE trending segments as it approached the surface from the south (Figure 2). He further suggested that rotation of the segments increased upward and that the top of each segment sloped upward to the north.

Major tectonic features around the Inyo Domes include the roughly ellipsoidal caldera-bounding faults and the N30W trending fault system of the Sierra Nevada block (Figure $1 a$ ). The immediate vicinity of the Inyo Domes contains normal faults and vertical fractures trending mostly $\mathrm{N} 15^{\circ} \mathrm{W}$ to $\mathrm{N} 20^{\circ} \mathrm{E}$ (Figure $1 b$ ) [Benioff and Gutenburg, 1939; Bailey et al., 1976; Miller, 1985; Fink, 1985; Mastin and Pollard, in press]. The trends of the Inyo area are apparent also in detail. For example, a 300-m-long fissure, known as Earthquake Fault, is found $6 \mathrm{~km}$ south of the Inyo Craters along the Inyo trend (Figure $1 b$ ); it is composed of many 2 - to 20 -m-long segments whose trends alternate within the same range of $\mathrm{N} 15^{\circ} \mathrm{W}$ to $\mathrm{N} 20^{\circ} \mathrm{E}$ (Figure 3 ).

The presence of the Inyo Dike was confirmed by the third drill hole of the Inyo Scientific Drilling Program [Eichelberger et al., 1985]. This slanted hole was sited between Obsidian Dome and South Glass Creek Dome (Figure $1 b$ ) where at a vertical depth of $620 \mathrm{~m}$, the hole intercepted a $7-\mathrm{m}$-wide rhyolite dike. The dike was surrounded by a 30-m-wide zone of fractures, some of which were filled with intrusive pyroclastic material. This dike did not vent to the surface at the drill hole area but fed the 35-m-wide conduit of Obsidian Dome, about $1 \mathrm{~km}$ north of the drill hole. The point of intersection was west of a line connecting the vent areas of the two domes, suggesting $10^{\circ}$ of clockwise rotation at this depth. The direction of this rotation was the same but the magnitude was less than the $25^{\circ}$ indicated by surface mapping [Fink, 1985].

The source for the Inyo lavas has been located at the northern end of the chain according to chemical considerations [Bailey et al., 1983], at its southern portion based on structural analysis [Fink, 


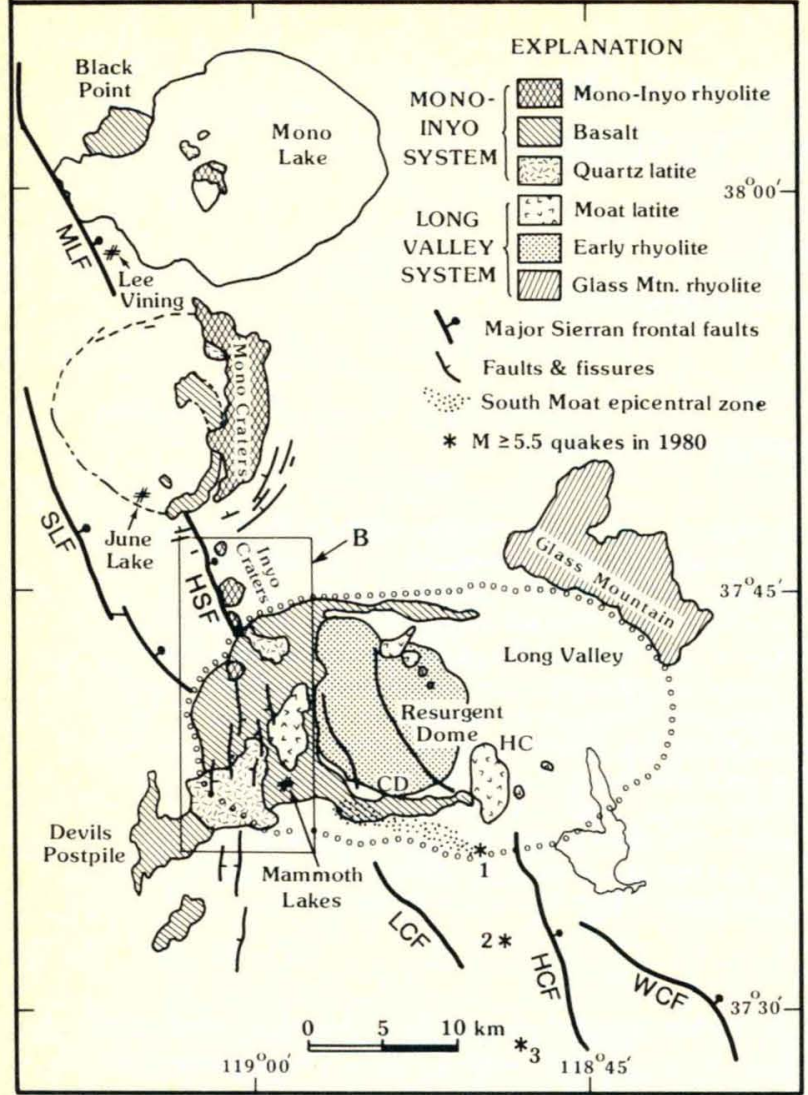

Fig. 1a. Simplified geologic map of Long Valley caldera and surrounding area, showing the distribution of post Bishop Tuff volcanic rocks, the Inyo/ Mono volcanic system, major faults, and three earthquake epicenters mentioned in the text [after Hill et al., 1985].

1985] or at several separate magma chambers along the chain [Sampson and Cameron, 1987]. While the Long Valley caldera is underlain by a large and shallow magma chamber, several geophysical techniques “... suggest a much smaller, less well defined dike-like chamber 10-20 km beneath the Mono [-Inyo] Craters chain" [Hill et al., 1985].

Geophysical data from the Inyo area have been collected as part of geothermal exploration, in conjunction with the Inyo Drilling Program, and in order to monitor the potential for future eruptions. Investigations concerning heat flow [Sorey, 1985; Blackwell, 1985], ground deformation [Savage and Cockerham, 1984], and seismic activity [Julian and Sipkin, 1985] are most important for the model developed below.

\section{EMPLACEMENT OF THE INYO DIKE}

An intruding dike may be envisioned as an internally pressurized fracture which propagates in the crust due to its dilation by molten magma. The dike extends when the forces which support its intrusion exceed the forces which resist the intrusion, and the dike stops under the opposite conditions. In the present section we evaluate the balance between these forces for the Inyo Dike.

The dike intrusion is supported by the following.

1. $P_{h}$, the hydrostatic pressure of the intruding magma which originates from the density difference between the molten magma and the solid rock.

2. $P_{v}$, the overpressure in the magma chamber from which the dike propagates. The most likely source for this overpressure is the undissolved volatiles in the magma [Blake, 1984].
3. The deviatoric tectonic stress normal to the dike, $\sigma_{t}$.

The dike intrusion is resisted by the following.

4. $P_{f}$, the fracture strength of the host rocks in the crust which has to be overcome.

5. $P_{\text {vis }}$, the pressure drop in the magma due to viscous resistance to flow of the magma.

6. $P$, the elastic resistance of the host rock to the intruding and dilating dike.

We define the sum of these stresses and pressures as the driving pressure $\left(P_{d}\right)$ of the dike. At depth $z$ below the surface the driving pressure is

$$
\left[P_{d}\right]_{z}=P_{h}+\sigma_{t}-P_{\text {vis }}+P_{v}-P_{f}-P_{e}
$$

Positive driving pressure indicates a propagating dike, whereas a vanishing driving pressure indicates a dike that stopped. Compressive stresses are positive.

When the dike intrudes into a uniform host rock, three of the terms on the right side of $(1 a), P_{v}, P_{f}$ and $P_{e}$, do not vary significantly with depth, and we rewrite $(1 a)$ as

$$
\left[P_{d}\right]_{z}=P_{\text {con }}+\left[P_{h}+\sigma_{t}-P_{\text {vis }}\right]_{z}
$$

where $P_{\text {con }}=P_{v}-P_{f}-P_{e}$ is a constant for a given dike configuration. Several investigators have designated the driving pressure as

$$
P_{d}=\left(P_{m}-\sigma_{t}\right)
$$

where $P_{m}$ is defined as the magma pressure in the dike [e.g. Pollard and Muller, 1976; Delaney et al., 1986]. From (1a) the magma pressure of previous studies is

$$
P_{m}=\left[P_{h}-P_{\text {vis }}\right]_{z}+P_{v}-P_{f}-P_{e}
$$

We demonstrate below that the six components of the driving pressure, including the five components of the magma pressure (equation $(1 c)$ ), may be separately calculated for the Inyo Dike. We first calculate the hydrostatic pressure, $P_{n}$, from the geometry of the dike, and the tectonic stress, $\sigma_{t}$, from the dike orientation and local crustal rheology. Then, the sum of constant pressures, $P_{\text {con }}$ and the viscous resistance, $P_{\text {vis }}$, are calculated from observations on the depth of the Inyo Dike. Finally, the magnitudes of the elastic resistance, $P_{e}$, and fracture strength, $P_{f}$, are derived from dike geometry.

\section{DePTH-Dependent PREsSuRes}

\section{Hydrostatic Pressure, $P_{h}$}

Consider the hydrostatic pressure on a dike which propagates from a magma chamber at depth $H$ to depth $z$; mean crustal density is $\rho_{r}$, and magma density is $\rho_{m}$. The lithostatic pressure due to the crustal rocks is $(\rho, g H)$ on the magma chamber and $(\rho, g z)$ at the tip of the dike. The hydrostatic pressure in the molten magma within the dike decreases from the lithostatic pressure $(\rho, g H)$ at the chamber depth, by $\left[\rho_{m} g(H-z)\right]$ at depth $z$ below the surface (Figure $2 b$ ). Thus the hydrostatic pressure in the magma at depth $z$ is the difference,

$$
\left(\rho_{r} g H\right)-\left[\rho_{m} g(H-z)\right]
$$

From this hydrostatic pressure we subtract the lithostatic pressure at depth $z$ and obtain the deviatoric hydrostatic pressure of the magma,

$$
\left[P_{h}\right]_{z}=\left(\rho_{r}-\rho_{m}\right) g(H-z)
$$

Tectonic Stresses, $\sigma_{\text {, }}$

Trend selection of the dike. Dikes usually propagate normal to the direction of the least compressive stress and grow by infiltration of 


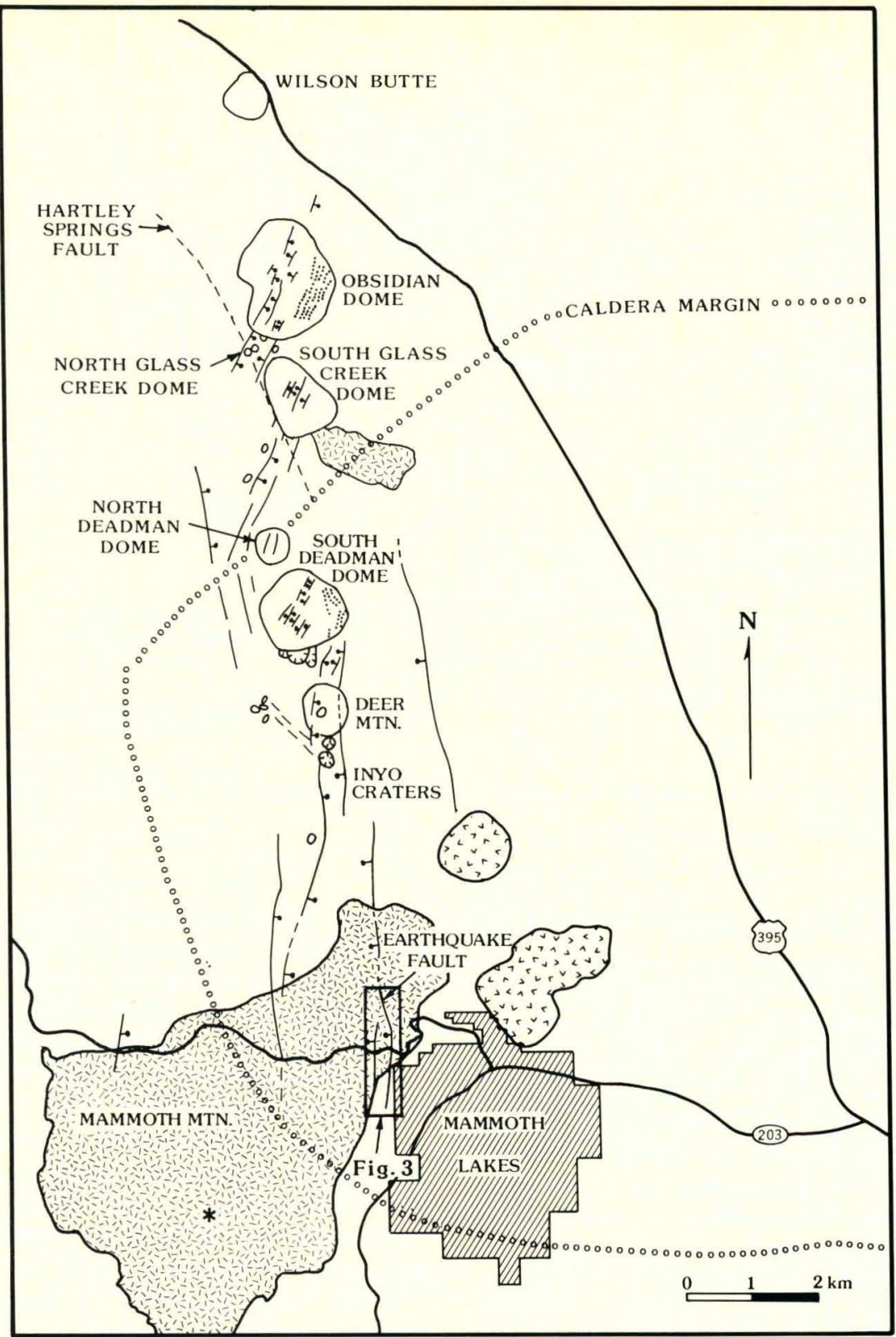

Fig. 1b. Map of the Inyo Domes area showing rhyolitic domes, phreatic craters, faults, cracks, and caldera margins. Location marked in Figure $1 a$ EF marks Earthquake Fault [after Fink, 1985].

magma into fractures [e.g., Anderson, 1938, 1951; Delaney et al., 1986]. Host rock enclosing the tip of a growing dike is dissected by old,preexisting fractures as well as by new fractures induced by the propagating magma. The magma invades the fractures having the mechanically most favorable orientation, regardless of their origin. The $\mathrm{N} 07^{\circ} \mathrm{W}$ alignment of the young Inyo Domes chain appears unaffected by two large, preexisting tectonic features. The first large structure is the active system of normal faults that bound the Sierra Nevada block. One of these, the Hartley Springs fault, trends $\mathrm{N} 30^{\circ} \mathrm{W}$ and intersects the Inyo chain along the west side of South Glass Creek Dome (Figure $1 b$ ). This fault indicates local horizontal extension in an $\mathrm{N} 60^{\circ} \mathrm{E}$ direction (Figure $4 a$ ). The second large feature is the conspicuous marginal zone and associated deepseated ring faults of Long Valley caldera. The ring fault system trends NE-SW at its intersection with the Inyo Craters chain between South Glass Creek Dome and South Deadman Dome
(Figure $1 b$ ) and thus indicates local horizontal extension in a NWSE direction across the caldera margin (Figure 4a). No change in dome alignment, eruption style, or magma composition has been detected close to these two intersections [Miller, 1985; Fink, 1985; Sampson, 1987]. Thus the growing Inyo Dike seems to have ignored both the fractures and the stress axes associated with the largest nearby preexisting tectonic features.

During its propagation at depth $z$, the Inyo Dike intrudes fractures trending $\mathrm{N} 07^{\circ} \mathrm{W}$ and ignores fractures trending NE-SW and $\mathrm{N} 30^{\circ} \mathrm{W}$ of the preexisting systems (Figure $4 a$ ). This trend selection implies that the driving pressure (equation (1a)) is larger for the $\mathrm{N} 07^{\circ} \mathrm{W}$ fracture trend than for the other two fracture trends. Of the six terms in $(1 a)$, only the tectonic stress, $\sigma$, varies with the fracture trend. Therefore we infer that the magma intruded the $\mathrm{N} 07^{\circ} \mathrm{W}$ fractures because the tectonic stresses associated with this trend are more intrusion supporting than the tectonic stresses asso- 


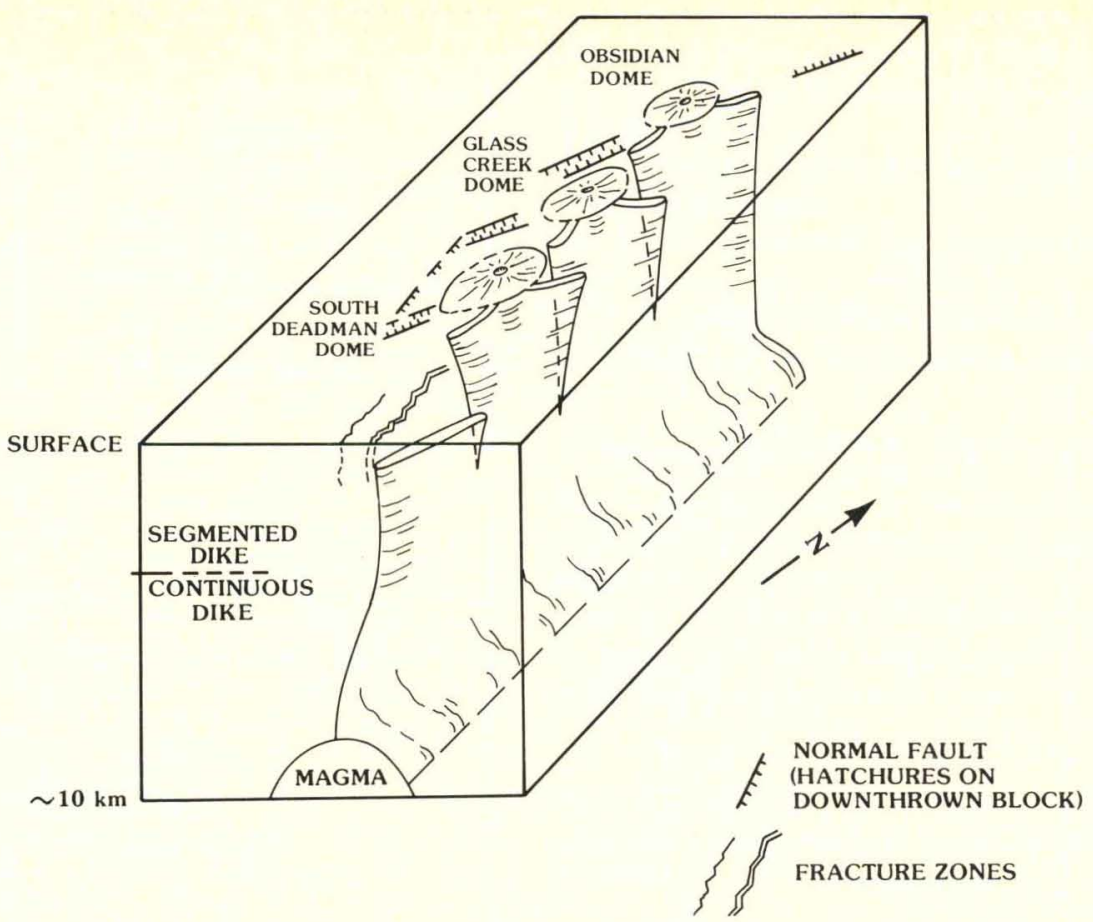

Fig. 2a. Schematic diagram showing inferred dike geometry beneath the Inyo Domes. Note that the dike is continuous at depth and segmented near the surface.

ciated with the other trends. We will examine this inference in detail.

In order for magma to invade an existing fracture, $P_{f}=0$; that is, the magma pressure should exceed the stress normal to the fracture's surface. The orientation of vertical fractures that can be dilated by magma pressure, $P_{m}$, were determined from Mohr circle relations by Delaney et al. [1986, equation 1] (Figure $4 a$ ). They found that fractures trending at an angle a with respect to $\sigma_{3}$ would be dilated by the magma if

$R=\left\{\left[\left(P_{m}-\sigma_{1}\right)+\left(P_{m}-\sigma_{3}\right)+2(\rho, g z)\right] /\left(\sigma_{1}-\sigma_{3}\right)\right\}>\cos (2 a)$

where $\sigma_{1}$ and $\sigma_{3}$ are the principal horizontal tectonic stresses. The term $2\left(\rho_{r} g z\right)$ appears in (3) because the magma pressure $P_{m}$ is defined here as the deviatoric pressure in the dike (equation 2 ), whereas the magma pressure is defined by Delaney et al. [1986] as the absolute pressure in the dike.

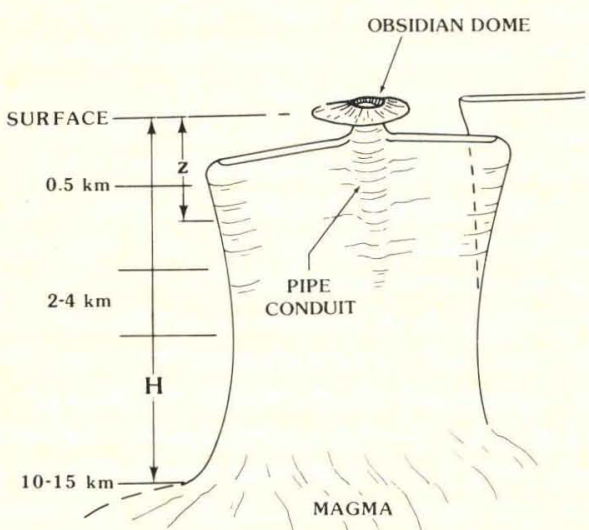

Fig. $2 b$. Detailed schematic view of Obsidian Dome segment showing development of widened pipe in center of segment and termination of dike a few hundred meters below the surface.
The curves in Figure $4 b$ are numerical solutions for the stress ratio $R$ of (3) for the three dominant structural systems in the Inyo area, $\mathrm{N} 07^{\circ} \mathrm{W}, \mathrm{N} 30^{\circ} \mathrm{W}$, and $\mathrm{N} 45^{\circ} \mathrm{E}$ (Figure $4 a$ ). For $R<-1$, the dike could not intrude any fracture, which indicates negative driving pressure; for $R>1$, the dike could intrude all fractures. For $-1<R<1$ the dike intrudes fractures trending as plotted in Figure $4 b$. Each stress state is represented by a point on Figure $4 b$; for example, point $G$ is for $\sigma_{1}$ trending $\mathrm{N} 10^{\circ} \mathrm{E}$ and $R=0.1$. The magma can only dilate a fracture if the point representing the stress state appears above the curve corresponding to that fracture. Consider $\sigma_{1}$ trending $\mathrm{N} 10^{\circ} \mathrm{E}$ (solid line in Figure $4 b$ ). For $R$ ranging from -1 . to -0.95 the stress states are below all curves, and thus no fracture can be dilated; for $-0.95<R<-0.4$ only trend a can be dilated; for $-0.4<R<-0.15$ fractures trending a and $\mathrm{b}$ can be dilated, and for $R>-.15$, all three trends can be dilated (Figure $4 b$ ). For this case, $\alpha_{a}=17^{\circ}, \alpha_{b}=40^{\circ}$ and $\alpha_{c}=35^{\circ}$ (Figure $4 a$ ).

The observation that the Inyo Dike ignored the two preexisting structures indicates that it trends normal to the least compressive tectonic stress direction during the intrusion, $N 83^{\circ} \mathrm{E}$. The development of the Inyo Dike along a trend which reflects a regional stress field rather than local structures is in agreement with other studies of paleostress; they show relatively uniform regional fields, on scales of tens to thousands of kilometers, which seem to ignore local structure [e.g., Zoback and Zoback, 1980; Eyal and Reches, 1983]. Further, the fact that the fractures oriented $\mathrm{N} 30^{\circ} \mathrm{W}$ and $\mathrm{N} 45^{\circ} \mathrm{E}$ were not intruded bounds the stress ratio: when the least compressive stress trends $\mathrm{N} 83^{\circ} \mathrm{E}$, the ratio is $-1.0<R<-0.65$ (Figure $4 b$ ); for $R>-0.65$, fractures trending $N 30^{\circ} \mathrm{W}$ would also have been invaded.

Tectonic stresses in the eastern Sierra Nevada. Tectonic stress data are not available for the Long Valley area, so here we employ the regional stress analysis of Zoback and Zoback [1980, 1987]. They found that the Sierra Nevada region includes both strike-slip and normal faulting, and it is transitional between the $\mathrm{San}$ Andreas 

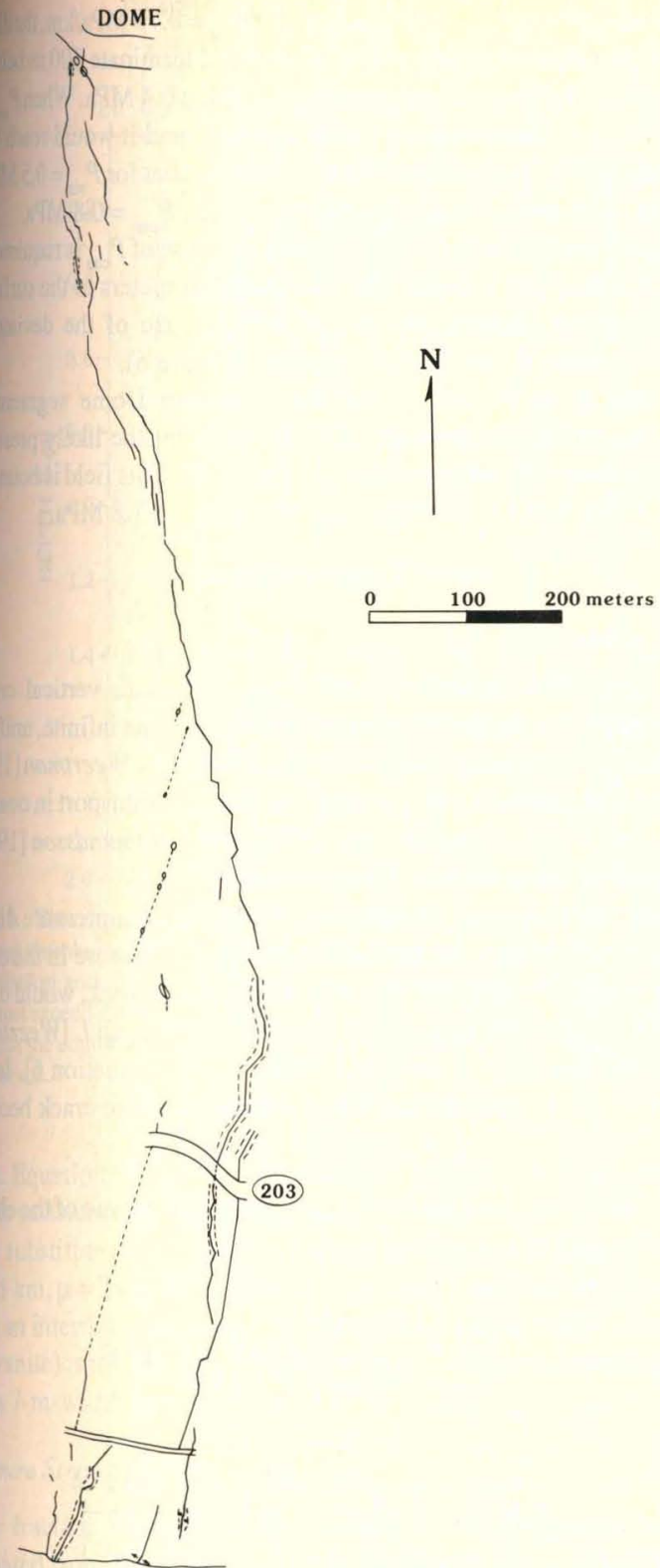

Fig. 3. Detailed map of Earthquake Fault and adjacent ground cracks in southem part of the Inyo Chain. Location indicated in Figure $1 b$. Note pattem of bimodal fracture trends. Lines dashed where trends inferred.

strike-slip province and the Cordillera extension province (Figure 5). They stated that, "detailed observations of faulting in the region of combined normal and strike-slip faulting (including broadly the Sierra Nevada-northern Basin and Range boundary zone and the Walker Lane belt of western Nevada) suggest temporal variations (possibly quite large) in both stress orientation and relative magnitudes" [Zoback and Zoback, 1987].

For the strike-slip events the stresses are $\sigma_{H \max }>\sigma_{\nu} \gg \sigma_{H \min }$, and for normal faults the stresses are $\sigma_{v}>\sigma_{H \max } \gg \sigma_{H \min }$, where $\sigma_{v}$, $\sigma_{H \max }$, and $\sigma_{H \min }$ are the vertical, maximum horizontal, and minimum horizontal stresses, respectively [Zoback and Zoback, 1987]. Using the results of McGarr and Gay [1978], we find for strike-slip faulting,

$$
\begin{array}{ll}
\rho, g z<\sigma_{1}<1.5 \rho_{r} g z & \left(\sigma_{1} \text { horizontal }\right) \\
\sigma_{2}=\rho_{r} g z & \left(\sigma_{2} \text { vertical }\right) \\
0.5 \rho_{r} g z<\sigma_{3}<\rho_{r} g z & \left(\sigma_{3} \text { horizontal }\right)
\end{array}
$$

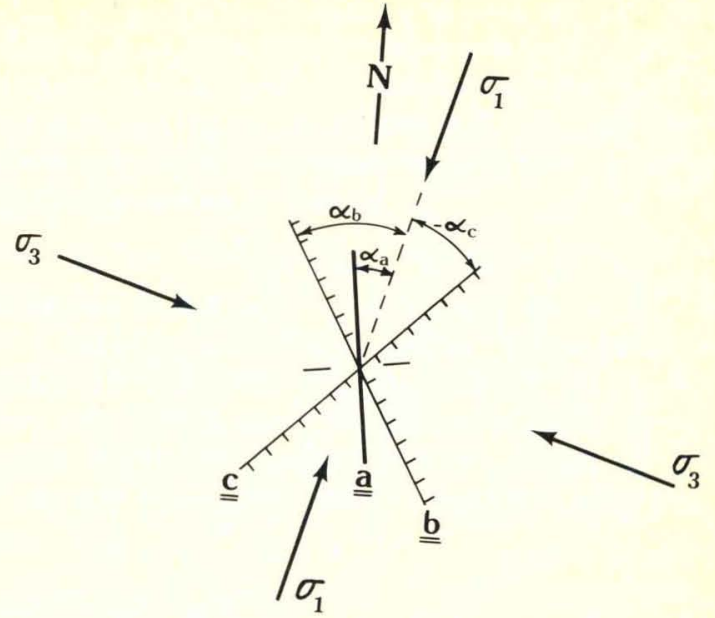

Fig. 4a. Idealized geometric relationship between the principal horizontal stresses, $\sigma_{1}$ and $\sigma_{3}$, in the Inyo Dike area and trends of major local structural features: a, trend of Inyo Dike, N07 W; b, trend of Hartley Springs Fault, $\mathrm{N} 30^{\circ} \mathrm{W}$; c, local trend of Caldera margin, $\mathrm{N} 45^{\circ} \mathrm{E}$.

and for normal faulting [Zoback and Healy, 1984],

$$
\begin{array}{ll}
\rho_{r} g z=\sigma_{1} & \left(\sigma_{1} \text { vertical }\right) \\
\sigma_{2}<\rho_{r} g z & \left(\sigma_{2} \text { horizontal }\right) \\
0.5 \rho_{r} g z<\sigma_{3} & \left(\sigma_{3} \text { horizontal }\right)
\end{array}
$$

The axes of $\sigma_{H \max }$ in eastern California and western Nevada trend mostly in a NNE to N-S direction with a few cases of NNW (Figure 5). The $N 07^{\circ} \mathrm{W}$ trend of $\sigma_{H \max }$, deduced above for the Inyo Dike (heavy line in Figure 5), appears to correlate with the observed regional distribution of trends of $\sigma_{H \max }$ (thin lines in Figure 5).

Stress distribution with depth. To determine the depth distribution of the tectonic stresses we make the following deductions. (1) The state of stress in the region of the Inyo chain is defined by (4), where $\sigma_{H \max }$ trends $N 07^{\circ} \mathrm{W}$ and $\sigma_{H \min }$ trends $\mathrm{N} 83^{\circ} \mathrm{E}$. (2) As the crust is continuously deformed, the long-term tectonic stresses within the crust are represented by its yield strength. (3) The rocks in the upper $10 \mathrm{~km}$ yield by fracturing when subjected to high strain rates according to the Griffith-Coulomb criteria.

The yield strength of the crust is usually derived for two distinct rheologies: frictional resistance to shear along fractures in the shallow, brittle rocks, and steady state creep in the lower, ductile rocks [e.g., Kirby, 1983]. The transition between the two rheologic

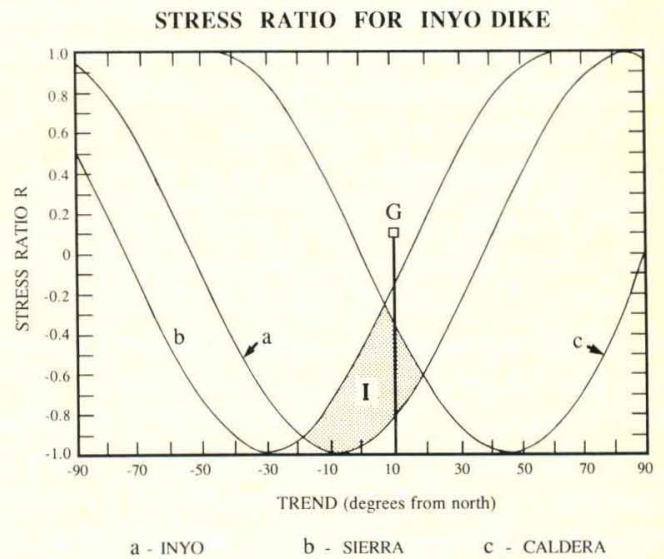

Fig. $4 b$. The stress ratio required for dilation by magma intruding into cracks oriented in directions $\mathrm{N} 07^{\circ} \mathrm{W}, \mathrm{N} 30^{\circ} \mathrm{W}$, and $\mathrm{N} 45^{\circ} \mathrm{E}(\mathrm{a}, \mathrm{b}$, or c trends from above) (after equation (3)). 


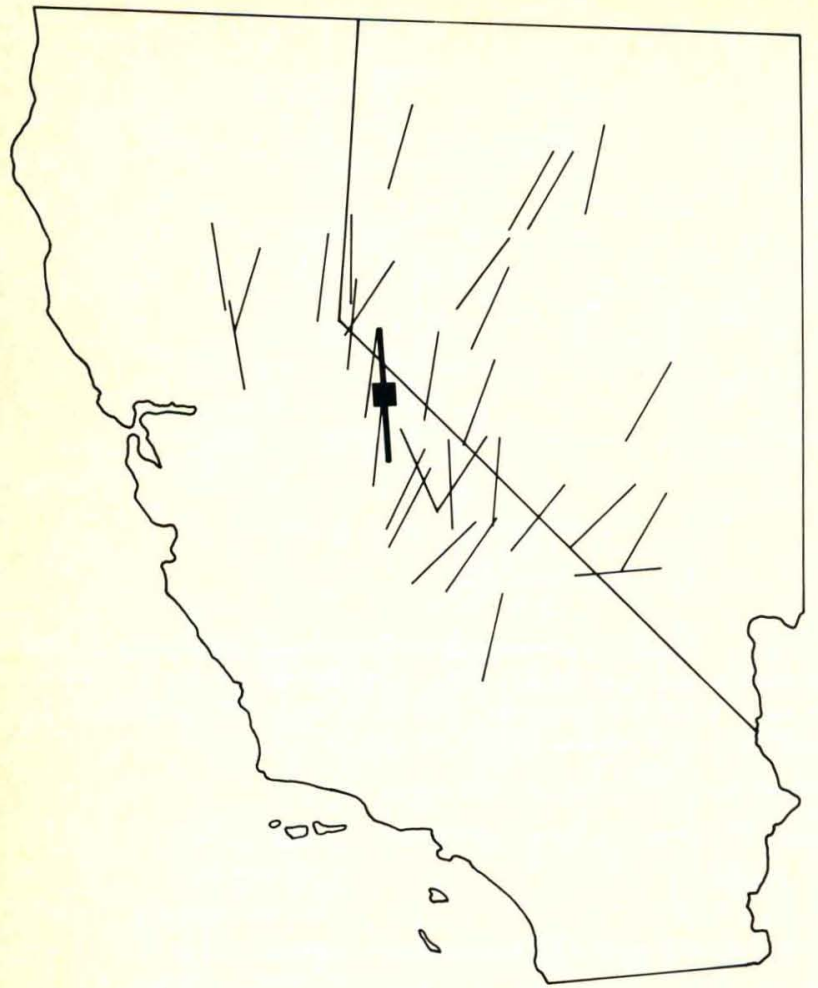

Fig. 5. The trends of the axes of maximum horizontal stress, $\sigma_{H \max }$ (thin, short lines), for western Nevada and eastern California; these trends were determined from in-situ stress measurements, earthquake focal plane solutions, and geological structures [after Zoback and Zoback, 1987]. The black square is the study area (Figure 1) and the thick, long line is the deduced trend of $\sigma_{H \max }$ for the Inyo Dike.

behaviors occurs at about $20-\mathrm{km}$ depth in crust with normal heat flow but may occur as shallow as a few kilometers in regions of high heat flow [Morgan and Golombek, 1984]. The high heat flow in Long Valley caldera suggests that the ductile-brittle transition is shallow.

Yield strength profiles for the Inyo area are calculated in the appendix and presented in Figure 6. This figure shows the maximum shear stress, $\sigma_{s}=\left(\sigma_{1}-\sigma_{3}\right) / 2$, that can be supported by the crustal rocks for the heat flow and crustal properties listed in the appendix. Figure 6 indicates that the upper $3-4.5 \mathrm{~km}$ of the crust deform by frictional slip, that $\sigma_{s}$ attains a maximum value of 24 $\mathrm{MPa}$ in the 3-4.5 km deep transition zone, and that $\sigma_{\mathrm{s}}$ decreases to about $3 \mathrm{MPa}$ for heat flow of $300 \mathrm{~m} \mathrm{Wm}^{-2}$, or vanishes for heat flow of $500 \mathrm{~m} \mathrm{Wm}^{-2}$ below a depth of about $10 \mathrm{~km}$.

\section{Pressure Drop due to Viscous Resistance, $P_{\text {vis }}$}

The termination of the Inyo Dike at depths less than $620 \mathrm{~m}$ implies that the driving pressure vanished at some depth $0<z<620 \mathrm{~m}$. By using the derived values of $P_{h}$ (equation (2)) and $\sigma_{i}$ (Figure 6), we calculate $P_{\text {con }}$ and $P_{\text {vis }}$, which satisfy vanishing driving pressure at depths shallower than $620 \mathrm{~m}$.

Rearranging ( $1 b)$ for vanishing driving pressure yields

$$
P_{\text {con }}=\left[P_{h}+\sigma_{t}-P_{\text {vis }}\right]_{z}
$$

The solution for this equation is shown in Figure 7 by substituting the results of (2) and the appendix. The figure displays the values of $P_{\text {con }}$ required to propagate a dike from a $10-\mathrm{km}$-deep magma chamber to the shown depths, for the marked $P_{\text {vis }}$, the pressure drop gradients in the dike. For example, for $P_{\text {vis }}=0.75 \mathrm{MPa} / \mathrm{km}$, the dike would propagate from a $10-\mathrm{km}$ depth and terminate $500 \mathrm{~m}$ below the surface if the constant pressure equalled $0.4 \mathrm{MPa}$. When $P_{\text {con }}>$ $0.4 \mathrm{MPa}$, the dike continues to propagate, and it would reach the surface for $P_{\text {con }}>3.3 \mathrm{MPa}$. Figure 7 shows that for $P_{\text {vis }}=0.5 \mathrm{MPa}$ $\mathrm{km}$, the dike would reach the surface when $P_{\text {con }}=0.8 \mathrm{MPa}$.

Figure 7 indicates that a significant increase of $P_{\text {con }}$ is required to move a dike from a depth of a few hundred meters to the surface. This property reflects the profound decrease of the deviatoric tectonic stress, $\sigma$, toward the surface (Figure 6).

According to Figure 7, for the Obsidian Dome segment to terminate at depths between 250 and $600 \mathrm{~m}$, the likely pressure conditions are included in the field marked I. This field is bounded by $0.5<P_{\text {vis }}<0.75 \mathrm{MPa} / \mathrm{km}$ and $-0.5<P_{\text {con }}<1.8 \mathrm{MPa}$.

\section{Depth-Constant Pressures}

\section{Elastic Resistance, $P$.}

The Inyo Dike is envisioned as an elliptical, vertical crack, subjected to internal pressure, and embedded in an infinite, uniform granite. Similar configurations were analyzed by Weertman [1971] who studied crevasses in glaciers and magma transport in oceanic ridges, and Pollard and Muller [1976] and Gudmundsson [1983], who applied the results to forms of dikes.

A closed crack in an elastic plate subjected to a pressure difference of $\Delta P$, between the internal hydrostatic pressure in the crack and the external hydrostatic pressure in the host rock, would dilate into an elliptical filled crack of width $W$ and length $L$ [Weertman, 1971, equation 15; Pollard and Muller, 1976, equation 6]. In the absence of tectonic stresses, the dimensions of the crack become

$$
\Delta P=(W / L)[\mu /(1-v)]
$$

where $\mu$ and $v$ are the shear modulus and Poisson ratio of the elastic

\section{MAXIMUM SHEAR STRESS IN INYO AREA}

STRENGTH (MPa)

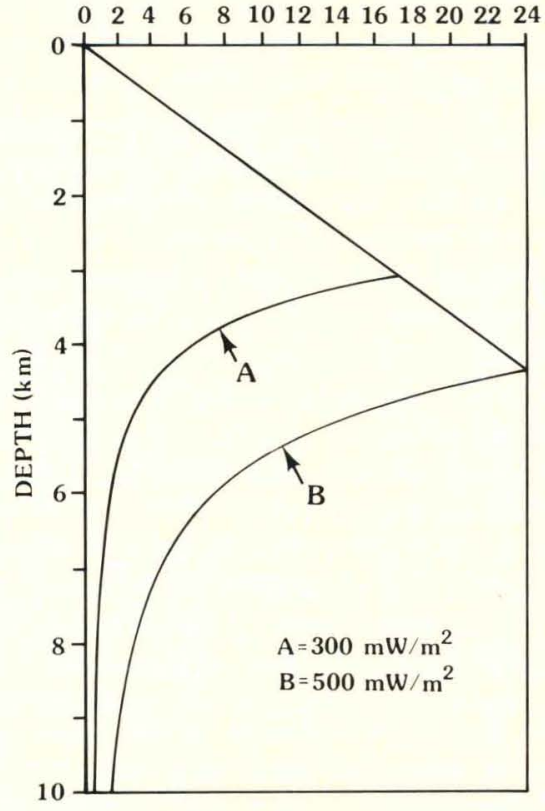

Fig. 6. The yield strength of the upper $10 \mathrm{~km}$ of the crust in the Inyo area as derived in the appendix. The diagram indicates strength profiles for mean heat flow of (a) $500 \mathrm{~m} \mathrm{Wm}^{-2}$ and $(b) 300 \mathrm{~m} \mathrm{Wm}^{-2}$. 


\section{DEPTH-CONSTANT PRESSURES}

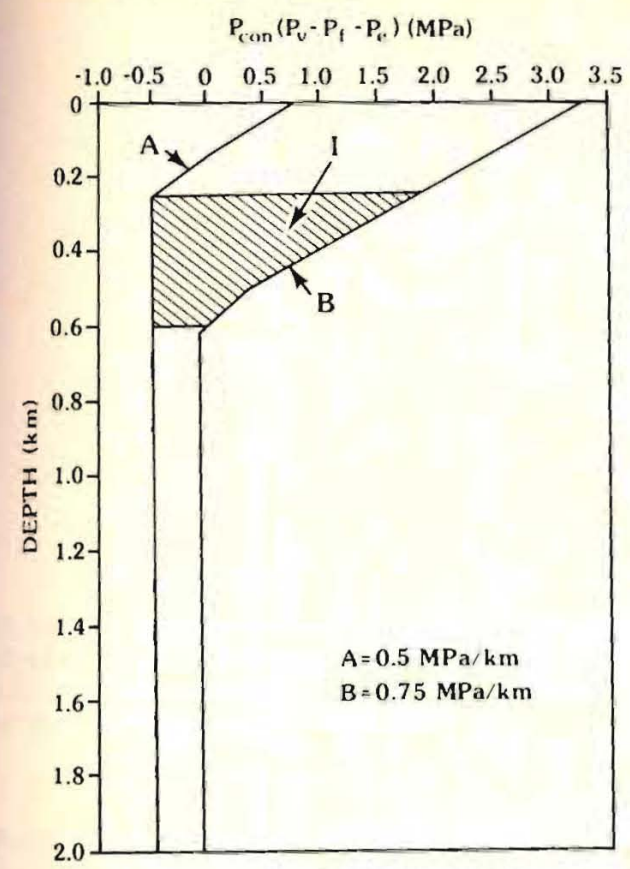

Fig. 7. The constant pressure, $P$, required to propagate a dike from a 10 $\mathrm{km}$ deep chamber to a depth of $2 \mathrm{~km}$ or shallower under a pressure drop of $(a)$ $0.5 \mathrm{MPa} / \mathrm{km}$ and $(b) 0.75 \mathrm{MPa} / \mathrm{km}$. Under pressure drop of $0.75 \mathrm{MPa} / \mathrm{km}$ $F_{\text {mom }}$ must exceed 3.3 MPa for the dike to vent to the surface. The field marked Ibounds the conditions for a dike to terminate at a depth of $250-600 \mathrm{~m}$ below the surface.

plate. Equation (5) shows the pressure required to overcome the elastic resistance of the plate; thus $P_{e}=\Delta P$.

We substitute the following values for the Inyo Dike: $W=7 \mathrm{~m}$, $L=11 \mathrm{~km}, \mu=20 \mathrm{GPa}$, and $v=0.1$ (granite), and find $P_{e} \cong 14 \mathrm{MPa}$. Thus an internal pressure of $14 \mathrm{MPa}$ (above lithostatic pressure in the granite) is necessary to dilate an $11-\mathrm{km}$-long fracture in granite inı a 7 -m-wide dike.

\section{Fracture Strength, $P$,}

The fracture strength of the granite in the Inyo area may be estimated from the dimensions of the dike. The third drill hole of the Inyo drilling project [Eichelberger et al., 1985] showed that the 7-m-thick segment of the Inyo Dike did not reach the surface and terminated at a depth of less than $620 \mathrm{~m}$, about $1 \mathrm{~km}$ south of Obsidian Dome. On the other hand, the 35-m-thick pipe under Obsidian Dome extends to the surface (Figure $2 b$ ) [Eichelberger et al., 1985, Figure 3].

Delaney and Pollard [1981] showed that magma transport in a quasi-circular pipe is more efficient than magma transport in a sheetlike dike. Thus piercement of the surface by the Obsidian Dome pipe and termination of the associated dike are expected. The dike and the pipe have the same composition [e.g. Vogel et al., 1987] and most likely were fed by interconnected conduits during a single eruption (Figure 2). Thus during the eruption, a hydrostatic balance existed between the pipe and its associated dike. The hydrostatic pressure at the top of the dike $\left[P_{h}\right]_{\text {dike }}$, at depth $z=z_{\text {top' }}$, is larger than the pressure at the top of the pipe $\left[P_{h}\right]_{\text {pipe }}$, at depth, $\imath=0$,

$$
\left[P_{h}\right]_{\text {pipe }}-\left[P_{h}\right]_{\text {dike }}=\left(\rho_{r}-\rho_{m}\right) g z_{\text {dike }}
$$

for $\rho_{r}<\rho_{m}$ (equation (2)).
During the eruption of Obsidian Dome, the larger pressure at the top of the dike was not sufficient to propag ate the dike upward, due to the resistance by the fracture strength of the granite $P_{f}$, the elastic resistance $P_{\text {, }}$, and the viscous resistance $P_{\text {vis }}$ (equation (1 $\left.a\right)$ ). We assume here that the only resistance to propagation was the fracture strength of the host rocks, namely,

$$
P_{f}=\left[P_{h}\right]_{\text {pipe }}-\left[P_{h}\right]_{\text {dike }}
$$

Thus the calculated $P_{f}$ is an upper limit for the strength. Taking $\rho_{,}=2670 \mathrm{~kg} / \mathrm{m}^{3}, \rho_{m}=2250 \mathrm{~kg} / \mathrm{m}^{3}$ (molten rhyolite [Williams and McBirney, 1979 , p. 29]), and $z_{\text {dito }}=250-600 \mathrm{~m}$, we obtain an estimate of the fracture strength as $1-2.5 \mathrm{MPa}$. These values express the in situ, overall maximum resistance to yielding of the intruded rocks and may not be directly transformed into fracture toughness values.

\section{Volatile Overpressure, $P_{v}$}

Figure 7 shows that the constant pressure, $P_{\text {con }}$, ranges from -0.5 to $1.8 \mathrm{MPa}$ for pressure drop due to viscous resistance of $0.5<P$ vis $<0.75 \mathrm{MPa} / \mathrm{km}$. The fracture strength and the elastic resistance were determined above from the dike dimensions, and now the volatile overpressure, $P_{v}$, can be estimated.

Equation $(1 b)$ indicates that

$$
P_{v}=P_{\text {con }}+P_{f}+P_{e}
$$

By substituting the above derived values of $-0.5<P_{\text {con }}<1.8 \mathrm{MPa}$, $1<P_{f}<2.5 \mathrm{MPa}$, and $P_{e} \cong 14 \mathrm{MPa}$ into this equation, we find a volatile overpressure which ranges from 14.5 to $18.3 \mathrm{MPa}$.

\section{The Driving Pressure of the Inyo Dike}

We examine here the depth variations of the driving pressure of the Inyo Dike (equation ( $1 a$ )), after the above derivation of all its six pressure components. Wc use the following parameters and results.

1. We assume that the tectonic shear stresses are equal in magnitude and distribution to the shear strength of the crust (appendix and Figure 6).

2. The tectonic stresses in the Sierra Nevada province are either of strike-slip faulting (equation (4a)), or of normal faulting (equation $(4 b)$ ). To simplify the following analysis, we suppose that during the intrusion of the Inyo Dike, the stresses around Long Valley were of strike-slip faulting (we will establish this assumption below) (equation (4a)), so that

$$
\sigma_{H \max }>\sigma_{v}>\sigma_{h \min }
$$

By substituting (6) into $(4 a)$, one gets $\sigma_{1}+\sigma_{3} \cong 2(p, g z)$, and thus the stress ratio of $(3)$ becomes

$$
R \cong P_{m} / \sigma_{s}
$$

Equations ( $4 a)$ and (6) also ind icate that $\left(\sigma_{1}+\sigma_{2}+\sigma_{3}\right) / 3 \cong \rho, g z$, and thus

$$
\sigma_{1} \cong \sigma_{3}-(\rho, g z) \cong-\left(\sigma_{1}-\sigma_{3}\right) / 2=\left|\sigma_{s}\right|
$$

where $P_{m}$ is the deviatoric magma pressure, $\sigma_{1}$ is the deviatoric tectonic stress normal to the Inyo Dike, and $\sigma_{3}=\left(\sigma_{1}-\sigma_{3}\right) / 2$, the crustal shear strength.

3. The parameters of the host rocks are: density $\rho_{r}=2670 \mathrm{~kg} / \mathrm{m}^{3}$, shear modulus $\mu=20 \mathrm{GPa}$, and Poisson ratio $v=0.1$ (mean values for granitic rocks in [Clark, 1966]). The density of the rhyolitic magma $\rho_{m}=2250 \mathrm{~kg} / \mathrm{m}^{3}$ [Williams and McBirney, 1979, p. 29].

4. Dimensions of the dike are: width $\mathrm{W} \cong 7 \mathrm{~m}$, length $\mathrm{L} \cong 11 \mathrm{~km}$, and depth of source $H \cong 10 \mathrm{~km}$. 
(a)

\section{TECTONIC, DRIVING, AND MAGMA} PRESSURES

\section{$\left(P_{\text {vis }}=0.55 \mathrm{MPa} / \mathrm{km}, \mathrm{P}_{\text {con }}=-0.45 \mathrm{MPa}\right)$}

DEVIATORIC STRESSES (MPa)

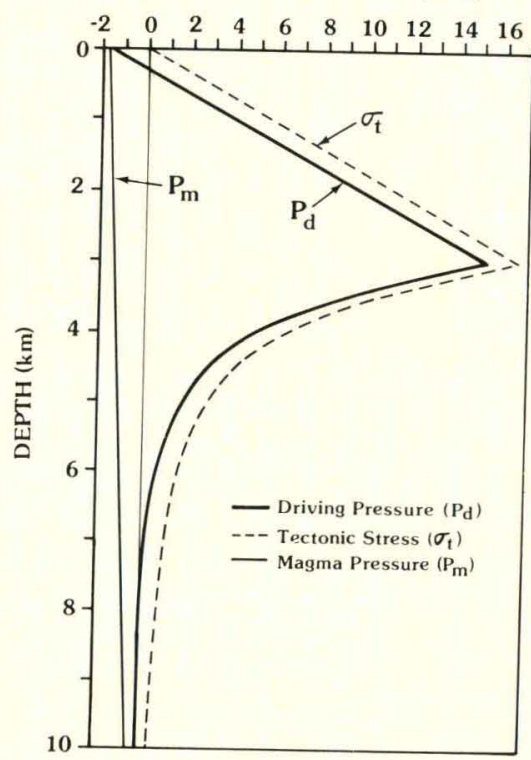

(b)

ABSOLUTE PRESSURES IN INYO DIKE

ABSOLUTE PRESSURES (MPa)

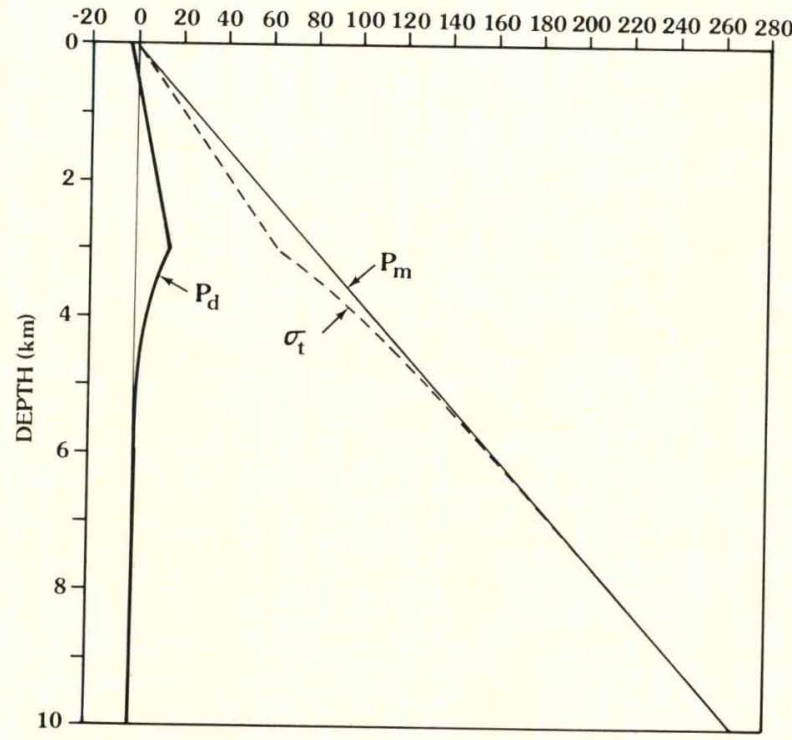

(c)

STRESS RATIO $\left(\mathrm{P}_{\mathrm{m}} / \sigma_{\mathrm{s}}\right)$ IN INYO DIKE

$\left(\mathrm{P}_{\text {vis }}=0.55 \mathrm{MPa} / \mathrm{km}\right)$

STRESS RATIOS $\left(\mathrm{P}_{\mathrm{m}} / \sigma_{\mathrm{S}}\right)$

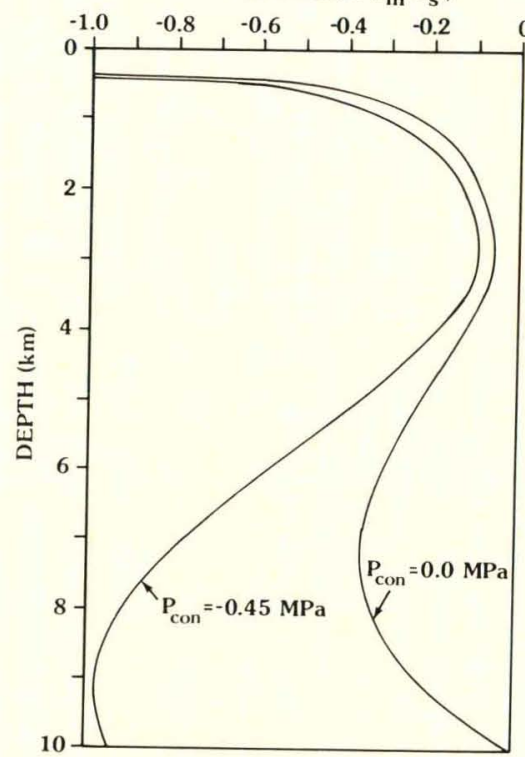

Fig. 8. The depth variations of the driving pressure $P_{d}$, the magma pressure $P_{m}$, the tectonic stress $\sigma_{1}$, and the ratio $R \cong P_{m} / \sigma_{\text {of }}$ of the Inyo Dike according to the present analysis; the solution is for $P_{\text {vis }}=0.55 \mathrm{MPa} / \mathrm{km}, P_{v}=14.5 \mathrm{MPa}, P_{f}^{m}=1 \mathrm{MPa}$, and $P_{\mathrm{e}}=14 \mathrm{MPa}$ (see text). (a) Deviatoric pressures (minus the lithostatic load), $(b)$ absolute pressures, and $(c)$ ratio $R$ of the deviatoric pressures (equation (7a)) 


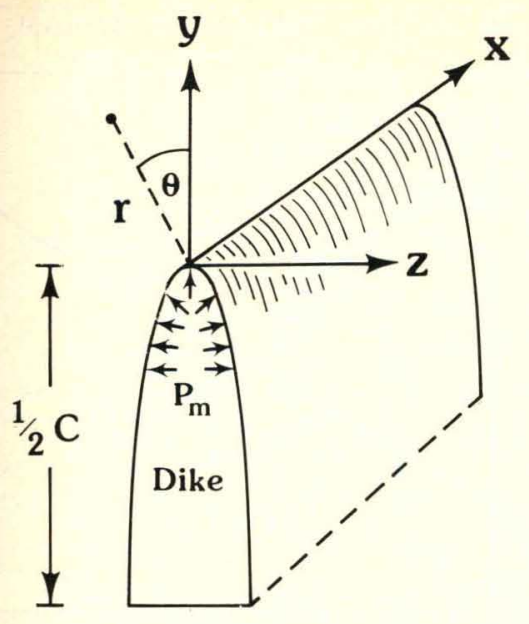

Fig. 9. The coordinate system for stresses at the tip of a pressurized crack. The $Y$ - $Z$ plane is normal to the planar crack. For the Inyo Dike, axis $X$ is the $\sigma_{1}$ axis (horizontal and trending $\mathrm{NO}^{\circ} \mathrm{W}$ ), axis $Y$ is the $\sigma_{2}$ axis (vertical), and axis $Z$ is the $\sigma_{3}$ axis (horizontal and trending $N 83^{\circ} \mathrm{E}$ ).

5. The following parameters were estimated in the above analysis: pressure drop due to viscous resistance $P_{\text {vis }}=0.5-0.75 \mathrm{MPa} / \mathrm{km}$, overpressure in the magma chamber $P_{v}=14-18 \mathrm{MPa}$, fracture strength $P=1-2.5 \mathrm{MPa}$, and elastic resistance to dike emplacement $P \cong 14 \mathrm{MPa}$.

We now examine depth variations of the driving pressure $P_{d}$ (equation(1a)), the magma pressure $P_{m}$ (equation (1c)) and the ratio $R$ (equation (7a)). At the depth of the magma chamber, $H$, the dike intruded only the $N 07^{\circ} \mathrm{W}$ fractures (see Figure $4 b$ and text); thus

$$
-1.0<R<-0.95 \quad z=H
$$

At depths shallower than $620 \mathrm{~m}$ where the dike stopped, no fracture was dilated; thus

$$
R<-1.0 \quad z<620 \mathrm{~m}
$$

Using the conditions of (8) and substituting the pressures listed in the paragraph above into (1) and (6), we derive the solution displayed in Figure 8. The deviatoric pressures $P_{d}, P_{m}$, and $\sigma_{t}$ are shown in Figure $8 a$, their absolute values (including the lithostatic load) are shown in Figure $8 b$, and the ratio $R \cong P_{m} / \sigma_{s}$ is shown in Figure $8 c$. The solution in Figure 8 is for $P_{\text {vis }}=0.55 \mathrm{MPa} / \mathrm{km}, P_{v}=$ 14.5 MPa, $P_{f}=1 \mathrm{MPa}$, and $P_{e}=14 \mathrm{MPa}$; this solution fits best the conditions of (8) and is bounded by the pressures derived above. In this solution, the deviatoric magma pressure $P_{m}$ changes linearly with depth from $-0.45 \mathrm{MPa}$ at $10-\mathrm{km}$ depth to $-1.7 \mathrm{MPa}$ at the surface (dotted line in Figure $8 a$ ), and the deviatoric tectonic stress varies nonlinearly with depth as derived in the appendix (thin line in Figure $8 a$ ). The driving pressure is the difference between the two pressures, $P_{d}=P_{m}-\sigma_{t}$ (solid line in Figure $8 a$ ). The driving pressure is positive for all depths below $500 \mathrm{~m}$ (namely, it supports dike intrusion), and negative for depths shallower than $500 \mathrm{~m}$.

\section{Discussion}

In the preceding analysis, we incorporated the depth variations of tectonic stresses in the Inyo area and estimated separate components of driving pressure of the Inyo Dike. We discuss below how these results may explain the rotation of segments of the Inyo Dike.

\section{Dike Segmentation and Rotation}

A propagating dike generates a local, nonuniform stress field close to its tip which modifies the uniform tectonic stress in the host rock. The principal stresses of the nonuniform field in front of the dike tip are tensional for positive driving pressure, $P_{d}>0$ [e.g., Jaeger and Cook, 1969, section 10.12]. We argue here that the reduction of tectonic stresses associated with these tensional stresses may explain segmentation of the Inyo Dike and rotation of its segments.

A dike may be modeled as a pressurized crack completely filled with magma or as a pressurized crack with a leading mode I crack which is not completely filled with magma. The stress field in the host rock is essentially identical for both configurations (compare (Jaeger and Cook, [1969, section 10.12] for pressurized crack and Lawn and Wilshaw [1975, equation 3.11], for mode I crack).

The stresses in a plane normal to a planar crack pressurized uniformly by magma, under plane strain conditions (Figure 9), were calculated by Jaeger and Cook [1969, section 10.12] and Lawn and Wilshaw [1975, equation 3.11]. For the Inyo Dike, axis $X$ is the $\sigma_{1}$ axis (horizontal and trending $N 07^{\circ} \mathrm{W}$ ), axis $Y$ is the $\sigma_{2}$ axis (vertical), and axis $Z$ is the $\sigma_{3}$ axis (horizontal and trending $N 83^{\circ} \mathrm{E}$ ). The stresses are,

$\sigma_{z z}=\left(P_{m}-\sigma_{t}\right)(0.5 C / r)^{1 / 2}\{\cos (\phi / 2)[1+\sin (\phi / 2) \sin (1.5 \phi)]\}$

$\sigma_{y y}=\left(P_{m}-\sigma_{t}\right)(0.5 C / r)^{1 / 2}\{\cos (\phi / 2)[1-\sin (\phi / 2) \sin (1.5 \phi)]$

$\sigma_{z x}=\left(P_{m}-\sigma_{t}\right)(0.5 C / r)^{1 / 2}\{\cos (\phi / 2)[\sin (\phi / 2) \cos (\phi / 2) \cos (1.5 \phi)]\}$

$\sigma_{x x}=v\left(\sigma_{z z}+\sigma_{y y}\right)$

where $C$ is the dike length, $r$ the distance from the dike tip, and $\phi$ the angle with the dike surface (Figure 9). As pointed out by Jaeger and Cook [1969, p. 263], for $P_{m}>\sigma_{t}$ the principal stresses in front of the dike, $\phi \cong 0$, and close to it, $C / r>2$ (Figure 9), are tensile. This profound reduction of the principal stresses strongly affects the style of fracturing in front of the dike as discussed below.

The Sierra Nevada granites fracture according to the GriffithCoulomb yield criteria which predict two modes of fracturing: extensional fractures for $\left(\sigma_{1}+3 \sigma_{3}\right)<0$ (conditions of small shear stresses and tensional $\sigma_{3}$ as shown by Mohr circle B in Figure 10b), and shear fractures when $\left(\sigma_{1}+3 \sigma_{3}\right)>0$ (conditions of large shear stress and large mean stress, $\left(\sigma_{1}+\sigma_{3}\right) / 2$ as shown by Mohr circle A in Figure 10a).

Consider the Inyo Dike as it propagates upward at about $10-\mathrm{km}$ depth. The tectonic stresses at this depth are $\sigma_{1} \cong 268 \mathrm{MPa}$ and $\sigma_{3}$ $\cong 266 \mathrm{MPa}$ (Figures 6 and 10b). (The Mohr circles in Figure 10 are not to scale. A circle for the stress state at $10-\mathrm{km}$ depth with $\sigma_{1} \cong$ $268 \mathrm{MPa}$ and $\sigma_{3} \cong 266 \mathrm{MPa}$ would be too small to see.) The magma intrudes into rocks subjected to large lithostatic stress and small differential stress; this state of stress is represented by Mohr circle $\mathrm{b}$ in Figure $10 \mathrm{~b}$. The reduction of the stresses in front of the dike to become tensile shifts the Mohr circle b to a new Mohr circle B (Figure 10b). This shift causes the circle to touch the GriffithCoulomb failure envelope at a position which indicates the formation of vertical extension fractures trending $\mathrm{N} 07^{\circ} \mathrm{W}$, perpendicular to the least compressive stress [see Secor, 1965; Julian and Sipkin, 1985, Figure 16]. The dike may now intrude into those fractures (Figure 10d).

During its upward propagation at a depth of $3.5 \mathrm{~km}$ the dike encounters a large tectonic shear stress of about $15 \mathrm{MPa}$, displayed by Mohr circle a in Figure $10 a$. The reduction of stresses in front of the dike again shifts the Mohr circle a leftward to a new Mohr circle A (Figure 10a). However, here the shifted Mohr circle touches the failure envelope at a position which indicates failure by shear fractures (Figure 10c). Under the tectonic stress of the Inyo area (equation (6)), the shear fractures would be vertical strike-slip faults (Figure 10c). Extension fractures do not form in the transition zone due to its large initial shear stresses. 
A
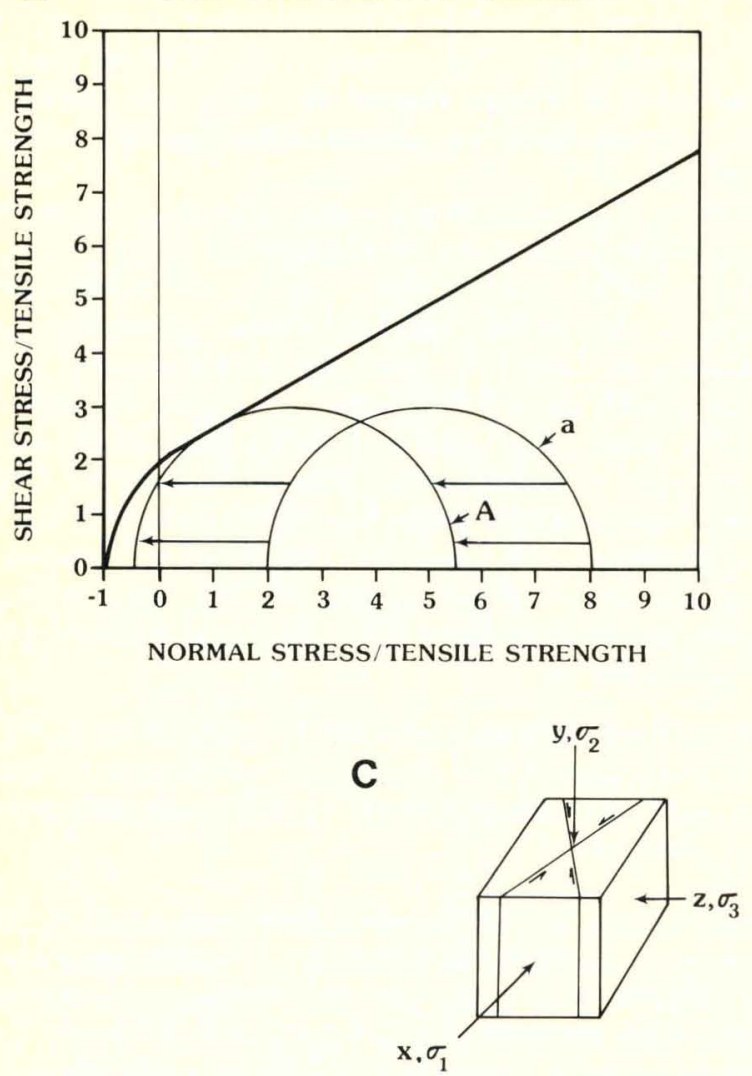

D

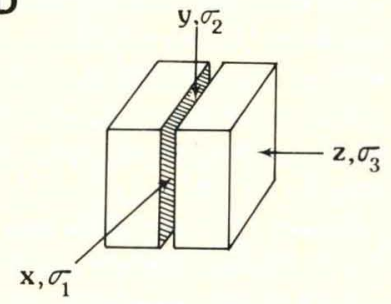

B

GRIFFITH-COULOMB DIAGRAM
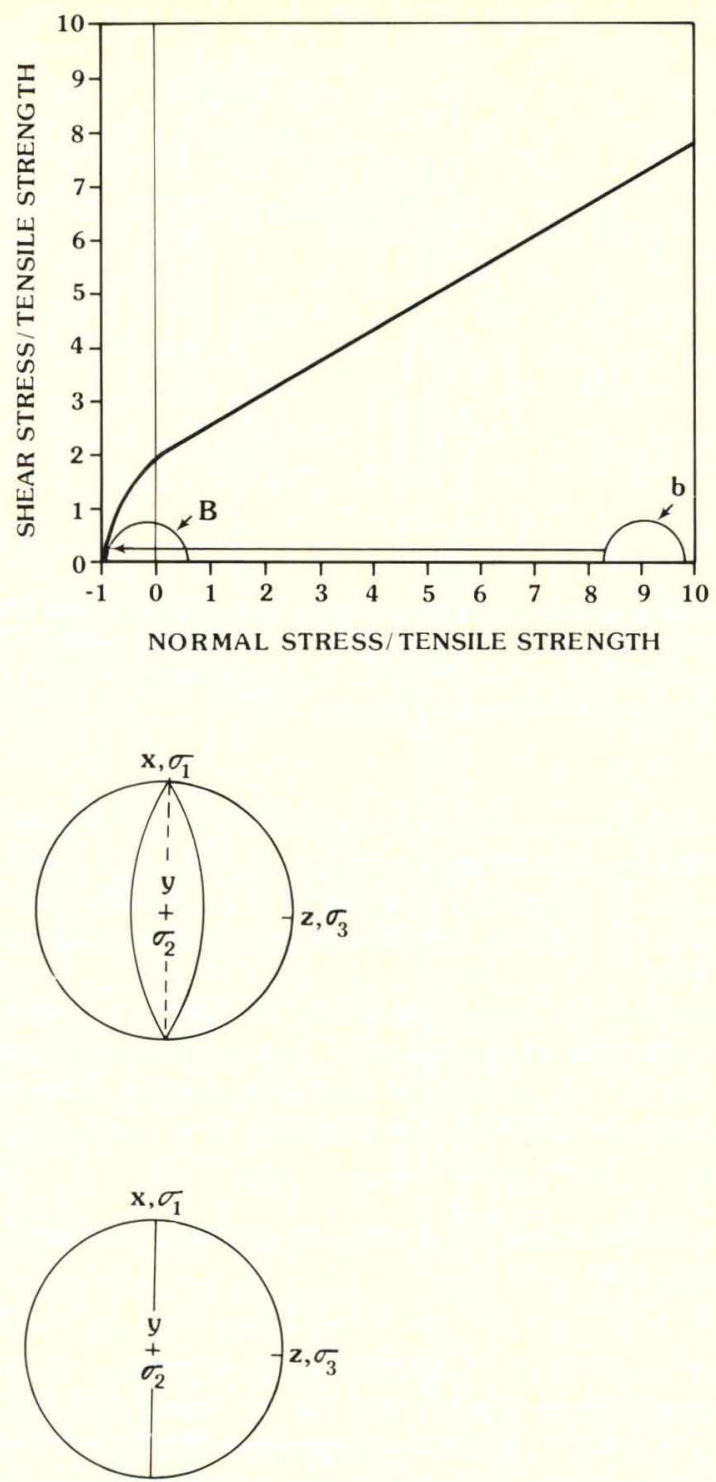

Fig. 10. ( $a$ and $b$ ) Schematic Mohr diagrams for the fracturing of crustal rocks during the propagation of the Inyo Dike (see text). The heavy curve is the Griffith-Coulomb yield envelope. Circles b and B (in Figure 10b) indicate the states of stress prior to and after the intrusion of the dike at depths of $10 \mathrm{~km}$ (see text). Note that circle B indicates extensional fracturing. Circles a and A (in Figure 10a) indicate the states of stress prior to and after the intrusion of the dike at a depth of $3 \mathrm{~km}$ (see text). Note that circle A indicates shear fracturing. (c) The geometry of the faults anticipated from the yielding shown by circle A, displayed in a block diagram (left) and a stereographic projection (right). (d) The geometry of the faults anticipated from the yielding shown by circle B, displayed in a block diagram (left) and a stereographic projection (right).

The conditions under which the Inyo Dike could dilate these shear fractures are delineated by (3) and Figure $4 b$. A vertical shear fracture which strikes from $\mathrm{N} 20^{\circ} \mathrm{W}$ to $\mathrm{N} 18^{\circ} \mathrm{E}$ may be intruded by the dike for stress ratios $R$ larger than -0.7 (Figure $4 b$ ); our calculations of $R$ (Figure $8 c$ ) indicate that at $3-\mathrm{km}$ depth $R \cong-0.2$ which is sufficient to dilate the predicted shear fractures.

The change in the mode of fracturing invokes a change in the trend of the dike. The deep extensional fractures trend $\mathrm{N} 07^{\circ} \mathrm{W}$ (Figure 10d), whereas the upper shear fractures trend in the range $\mathrm{N} 37^{\circ} \mathrm{W}$ to $\mathrm{N} 23^{\circ} \mathrm{E}$ (Figure $10 \mathrm{c}$ ). Therefore the passage of magma from the deep extensional fracture to the shallower shear fractures allows for rotation of the dike segment in the transition zone. The change in the fracturing mode would occur at several locations along the tip of the Inyo Dike in the transition zone. Thus intrusion of the magma into the rotated shear fractures also would occur in several locations and the dike should have split into several segments (Figure 2).

In summary, the process described above demonstrates that the Inyo Dike would have propagated from the magma chamber in selfinduced extensional fractures due to small shear stress in the ductile region of the crust (Figures $10 b$ and $10 d$ ). In the transition zone from ductile to brittle rheology, at a depth of about $3 \mathrm{~km}$, the mode of fracturing changes from extensional to shear due to the large shear stresses (Figures $10 a$ and $10 c$ ). The dilation of shear fractures rather than extension fractures results in rotation of the dike and segmentation (Figure 2). We thus conclude that segmentation and 


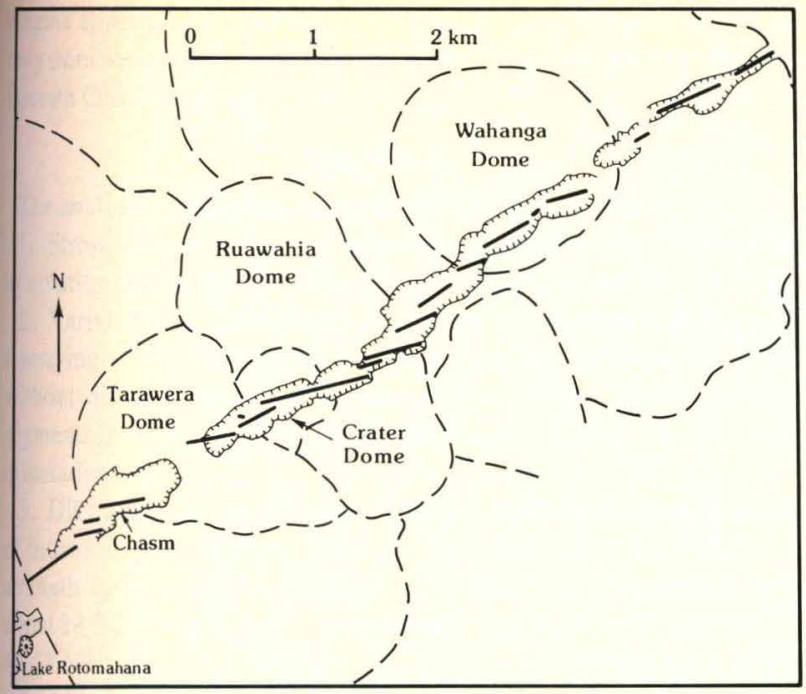

Fig. 11a. Map of Tarawera Dome complex showing observed and inferred positions of en echelon basaltic dike segments (dark lines) that erupted in 1886. Map location shown in Figure $10 b$ [after Nairn and Cole, 1981].

rotation may be the consequences of changes in rheology and fracturing mode of the crust in a region of high heat flow.

The proposed mechanism of dike intrusion into shear fractures explains and is supported by several observations.

1. The trends of surface fractures in the Inyo area display bimodal distributions. This is apparent in the map of large-scale faults and fracture zones (Figure $1 b$ ), as well as in the details of one fracture zone, the Earthquake Fault (Figure 3). Although direct inclinations are difficult to measure, all exposed fractures are very steep to vertical. We interpret these fractures as incipient subvertical strike-slip fractures which have been dilated. The vertical attitude and the bimodal trend distribution support the above suggestion that the strike-slip stress conditions existed during the Inyo Dike intrusion (equation 6); however, unambiguous shear displacements have not been documented.

2. The Obsidian Dome segment of the Inyo Dike seems to rotate gradually as it rises. Surface mapping suggests a trend of about $\mathrm{N} 18^{\circ} \mathrm{E}$ (Figure $1 b$ ), whereas the drill core indicates a trend of $\mathrm{N} 06^{\circ} \mathrm{E}$ at $620-\mathrm{m}$ depth (Figure $2 b$ ) [Fink, 1985]. The inclination of the segment is unknown. If the rotation in the upper $620 \mathrm{~m}$ is part of a uniform, gradual rotation from the main Inyo Dike, then this segment should merge with the $\mathrm{N} 07^{\circ} \mathrm{W}$ trending main dike at a depth of about $1200 \mathrm{~m}$. The calculations in the above section for depth of the transition zone indicated $3 \mathrm{~km}$; we regard these depths as bounding values.

3. Most segments of the Inyo Dike appear to be rotated clockwise, with the possible exception represented by the NNW trending fracture zone southeast of Deer Mountain [Mastin and Pollard, in press] (Figures $1 b$ and 2). We speculate that this preferred sense of rotation is caused by release of shear stress along intruded shear fractures. Both clockwise and counterclockwise trending shear fractures would be available in the transition zone (Figure 10c). If a clockwise trending fracture were intruded first by the magma, then shear stress parallel to the fracture would relax. Relaxation of the shear stress causes a local rotation of the horizontal principal stress axes in a clockwise sense. Because such stress rotation increases the tendency of clockwise fractures to be intruded by the magma, the process will amplify itself, leading to eventual domination by one trend.

\section{Applications of the Present Analysis}

Even though the present analysis is based on measurements in and around the Inyo Chain, it may provide some insight into other sheet intrusions in Long Valley caldera and elsewhere.

Rotated segments of dikes and sills have been observed in many locations [e.g., Pollard et al., 1975; Delaney and Pollard, 1981]. Pollard et al. [1982] proposed that segment rotation occurs in response to rotation of the least compressive stress axis. We have demonstrated here that the rotation may also occur due to variations in host rock rheology and fracturing style.

One prediction of the current model is the occurrence of bimodal fracture patterns accompanying dike intrusion as manifested along the Inyo trend in the detailed structure of Earthquake Fault (Figure 3). Similar bimodal fracture patterns occur in other sites above shallow dikes. The Tarawera eruption of 1886 in New Zealand was fed by a $30-\mathrm{km}$-long $\mathrm{N} 30^{\circ} \mathrm{E}$ trending basaltic dike whose segments show a consistent clockwise rotation of $15^{\circ}$ (Figure $11 a$ ) [Nairn and Cole, 1981]. Regional mapping in the Tarawera area reveals two main sets of faults oriented $\mathrm{N} 10^{\circ} \mathrm{E}$ and $\mathrm{N} 45^{\circ} \mathrm{E}$ (Figure $11 \mathrm{~b}$ ) [Wilson et al., 1984]. A second ex ample is provided by ground cracks along the trend of Little Glass Mountain and adjacent rhyolite domes of the Medicine Lake Highland Volcano in California. The patterns of vents and faults indicate a NE trending dike whose segments rotated clockwise [Fink and Pollard, 1983]; in detail however, the fracture pattern shows a bimodal distribution (Figure 12). These patterns indicate possible application of the present model, but additional study is required to fully ascertain this suggestion.

Our study also offers an explanation for two controversial geophysical observations in Long Valley caldera. The first case concerns the analysis of focal mechanisms for three earthquakes that occurred in 1980 at depths of 7-10 km, south of the caldera (locations shown in Figure 1a). One interpretation implies that these are double-couple shear events associated with complex shear surfaces [Wallace, 1985; Lide and Ryall, 1985; Priestly et al., 1985), whereas the alternative model suggests that these events indicate dilation phenomena associated with rapid intrusion of magma into NNW-SSE trending cracks [Julian and Sipkin, 1985;

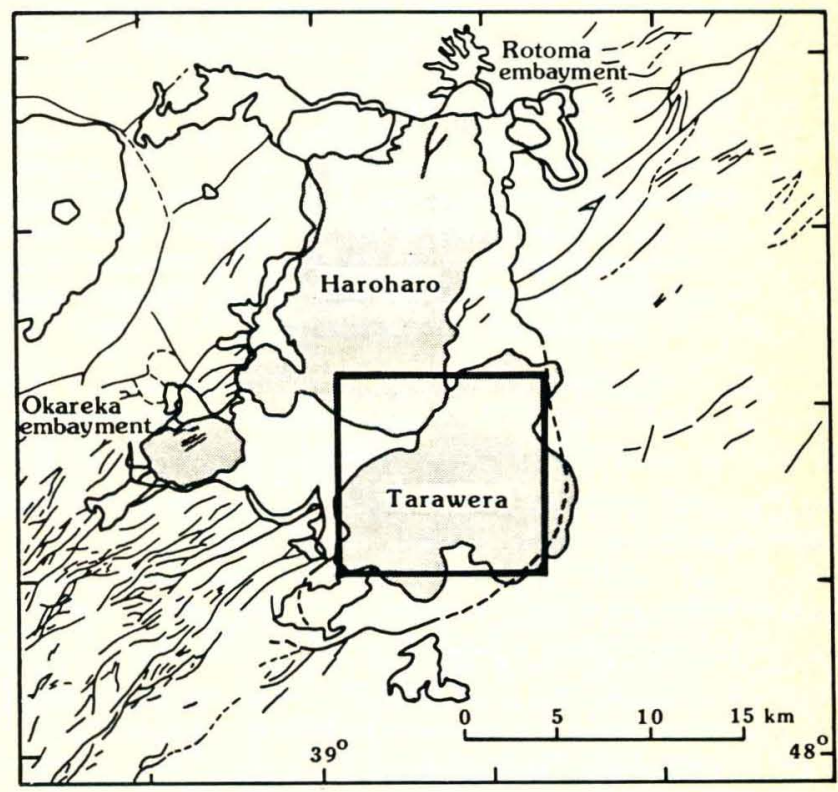

Fig. 11b. Map of faults in the vicinity of Tarawera Complex, New Zealand. Note bimodal distribution of orientations. Shaded areas, silicic volcanic rocks; dashed line, margin of caldera [after Wilson et al., 1984]. 


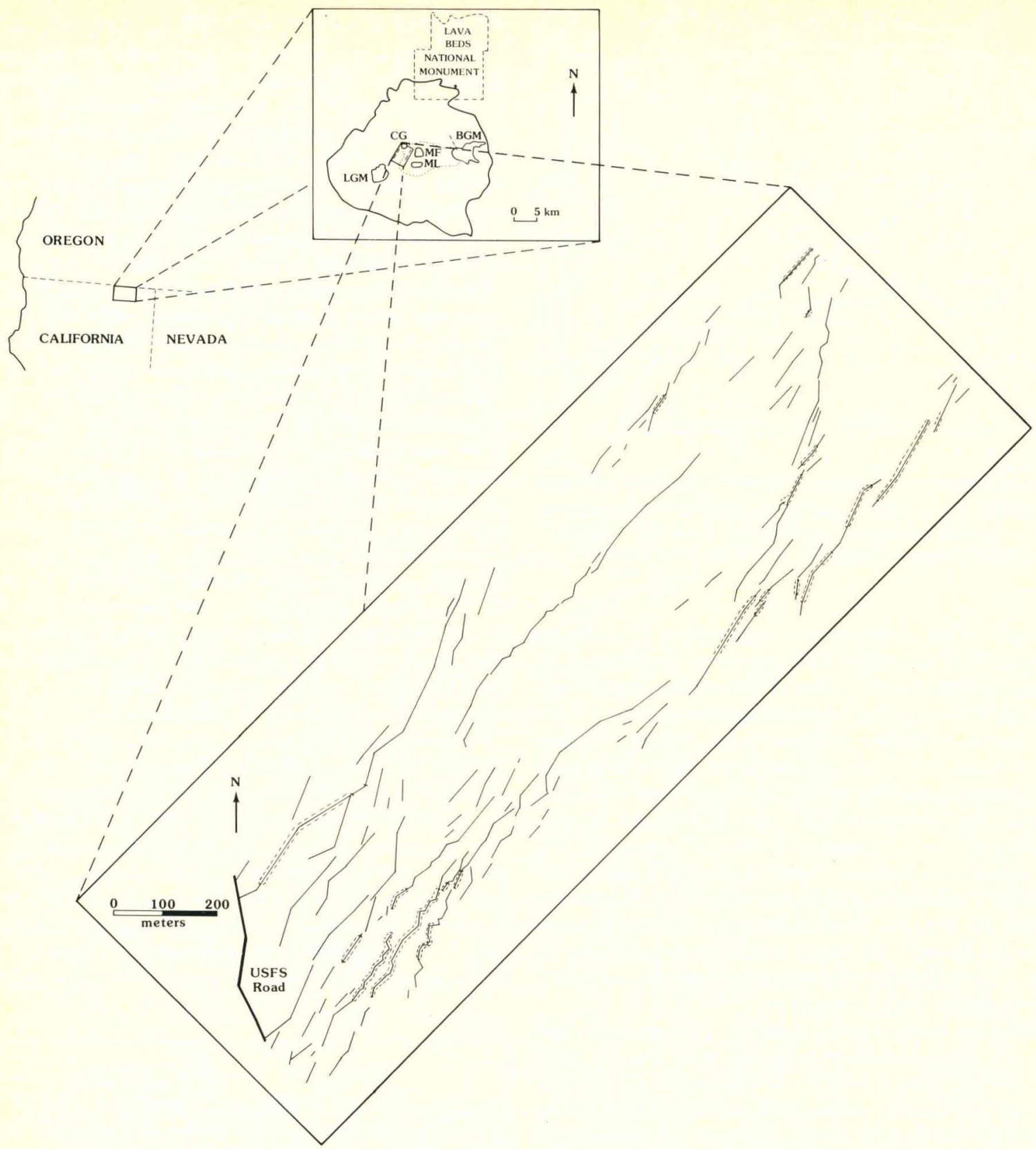

Fig. 12. Map showing ground cracks over inferred northeast trending silicic dike(s) northeast of Little Glass Mountain rhyolite flow on the Medicine Lake Highland Volcano, California. Features indicated on the inset map include Little Glass Mountain (LGM), Big Glass Mountain(BGM), Crater Glass Flow (CG), Medicine Lake dacite flow (MF), Medicine Lake (ML), caldera margin (dotted line), and ground crack trends (dashed lines). On main crack map, segments with more than 5-m horizontal separation indicated by dotted lines. Note zigzag pattern of crack trends.

Chouet and Julian, 1985]. The second interpretation is in accord with the present analysis that predicts extensional fracturing due to magma intrusion as deep as $10 \mathrm{~km}$.

The second set of controversial observations involves recent deformation data collected within Long Valley caldera. Savage and Cockerham [1984] showed that ground deformation that occurred in 1983 could be explained by the dilation of an intrusive body extending from a depth greater than $10 \mathrm{~km}$ to a level about 3 $\mathrm{km}$ below the surface. Although the explicit shape of the intrusion could not be uniquely resolved, they indicated that the deformation could be accounted for by inflation of a sill inclined $30^{\circ}$ between depths of 12 and $8 \mathrm{~km}$ that fed a vertical dike extending from depths of $8-3 \mathrm{~km}$. The observed surface deformation would require 0.39 $\mathrm{m}$ inflation of the sill and $0.15 \mathrm{~m}$ for the dike.

The model of Savage and Cockerham raises the question as to why magma should rise from depths of $12 \mathrm{~km}$ to within $3 \mathrm{~km}$ of the surface without erupting. If an intrusion in 1983 had dimensions on the order of tens of centimeters, it would have frozen before reaching the surface. However, our analysis indicates that even for a width on the order of $10 \mathrm{~m}$ (for which the cooling rate would not be significant), an intrusion could not reach the surface unless the volatile overpressure exceeded the host rock fracture strength by at least $18 \mathrm{MPa}$. This constraint is supported by the pattern of Holocene silicic activity in the Inyo and Mono Craters areas where 
magma approached the surface in several long dikes but erupted only from wide pipelike vents such as the one penetrated by drilling beneath Obsidian Dome.

\section{Conclusions}

The analyses presented here indicate the following:

1. Stress fields of continental scale may prevail and control dike orientation even in the vicinity of large and active tectonic features. 2. Variations in crustal rheology and the related variation of fracturing style may cause segmentation and rotation of dikes without direct rotation of the stress axes. Thus trends of dike segments may be indicators of rheology as well as of stress orientation.

3. Dike geometry provides bounds on the mechanical parameters of intrusion. For the Inyo Dike we find that extensional fracture strength is $1-2.5 \mathrm{MPa}$, the elastic resistance to dike intrusion is about $14 \mathrm{MPa}$, the volatile overpressure in the magma chamber is $14-18 \mathrm{MPa}$, and the pressure drop in the propagating dike is about $0.55 \mathrm{MPa} / \mathrm{km}$.

4. Propagation of dikes becomes increasingly difficult as they near the surface due to the upward decrease in tensile strength and the corresponding reduction in tensile stress magnitude. Cessation of dike rise may thus result from an upward decrease in the influence of regional tensile stresses, rather than from cooling and solidification. This process may explain why the Inyo Dike stopped rising only a few hundred meters below the surface at the Inyo Craters and at the site of the RDO-3A drill hole.

\section{APPENDIX}

We derive here the crustal strength variations with depth in the vicinity of the Inyo chain using the following procedure: (1) calculate the depth/temperature profile, (2) calculate the frictional strength of the crust, assuming it varies linearly with depth and it is independent of temperature or rock type, and (3) obtain the yield strength for steady state creep by assuming power law rheology. The first step is calculating the temperature profile. Following Turcotte and Schubert [1982, equation 4-31],

$$
T=T_{s}+Q_{m}(h / k)+\left(Q_{s}-Q_{m}\right) H[1-\exp (-h / H)] / k
$$

where $T_{s}$ is surface temperature, $Q_{m}$ and $Q_{s}$ are the heat flow of the mantle and the surface, respectively, $\mathrm{h}$ is the depth, $H$ is characteristic depth length, and $k$ is the thermal conductivity. The details of the geothermal system in Long Valley caldera are partly obscured by the intensive hydrothermal activity [Sorey, 1985; Blackwell, 1985]. Furthermore, the Inyo Chain is partly outside the caldera (Figure $1 a$ ), and thus the data collected in the caldera may serve only as an estimate. The mean heat flux in the Long Valley caldera, calculated by dividing the total heat discharge by the caldera area, is $630 \mathrm{~mW} \mathrm{~m}^{-2}$ [Sorey, 1985, Table 1]. The thermal conductivity $k$ ranges from $1.05 \mathrm{~W} \mathrm{~m}^{-1} \mathrm{~K}^{-1}$ for the post-Bishop Tuff rocks (Blackwell, 1985 , p. 11,236$)$ to $3.1 \mathrm{~W} \mathrm{~m}^{-1} \mathrm{~K}^{-1}$, the mean thermal conductivity for granite [Clark, 1966], which is the basement rock in the Inyo area [Eichelberger et al., 1985].

We take for the Inyo area two bounding values of surface heat flow, $Q_{s}=300 \mathrm{~m} \mathrm{Wm}^{-2}$ and $Q_{s}=500 \mathrm{~m} \mathrm{Wm}^{-2}$, thermal conductivity of $k=3.0 \mathrm{Wm}^{-1} \mathrm{~K}^{-1}$, and also $T_{s}=10^{\circ}, H=10 \mathrm{~km}$, and $Q_{m}=30 \mathrm{~m}$ $\mathrm{Wm}^{-2}$ [Turcotte and Schubert, 1982]. The calculated temperatures are used as input for (A2) below.

The second step is calculating yield strength for steady state creep of crustal rocks from the power law creep equation [Weertman and Weertman, 1975] as modified for crustal flow by Lynch and Morgan [1987],

$$
\sigma_{1}-\sigma_{3}=\left(E / E_{\mathrm{o}}\right)^{1 / n} \exp [(Q+P V) /(n R T)]
$$

where $\sigma_{1}$ and $\sigma_{3}$ are the maximum and minimum principal stresses, $E$ is the strain rate, $E_{\mathrm{o}}$ and $n$ are rock constants, $Q$ is the activation energy, $V$ is the activation volume, $P$ is the pressure, $R$ is the gas constant, and $T$ is the temperature [see also Kirby, 1983]. Following Lynch and Morgan [1987, Tables 1 and 2], $n=3, P V=$ $293 \mathrm{~J} / \mathrm{mol} \mathrm{km}$, and for siliceous rocks, $Q=1.4 \times 10^{5} \mathrm{~J} / \mathrm{mol}$ and $E_{\mathrm{o}}=$ $2.5 \times 10^{-8} \mathrm{MPa}^{-3} \mathrm{~s}^{-1}$. By substituting these values and the temperatures derived from (A1) into (A2), we determine the lower part of the strength curves shown in Figure 6.

The third step is determining the strength of the brittle part of the crust due to frictional resistance along shear fractures. For extensional conditions it is $5.5 \mathrm{MPa} / \mathrm{km}$ [Lynch and Morgan, 1987]. This strength composes the upper part of the curve in Figure 6.

Acknowledgments. The authors thank Roger Denlinger, David Pollard, Agust Gudmundsson, Michael Malin, and Curtis Manley for helpful comments, Matt Golombek and Mark Zoback for constructive reviews, Sue Selkirk for drafting the figures, and Nina De Lange for editorial assistance. Research supported by Department of Energy grant DE-FG02-85ER43320 as part of the Inyo Scientific Drilling Program, NSF grant EAR 8309500, and NASA grant NAGW 529 from the Planetary Geology Program.

\section{REFERENCES}

Anderson, E. M., The dynamics of sheet intrusion, Proc. R. Soc. Edinburgh, $58,242-251,1938$.

Anderson, E. M., The Dynamics of Faulting and Dyke Formation With Applications to Britain, 206 pp., Oliver and Boyd, Edinburgh, 1951.

Bailey, R. A., G. B. Dalrymple, and M. A. Lanphere, Volcanism, structure, and geochronology of Long Valley caldera, Mono County, California, $J$. Geophys. Res., 81, 725-744, 1976.

Bailey, R. A., R. A. Macdonald, and J. E. Thomas, The Inyo-Mono Craters: Products of an actively differentiating rhyolite magma chamber, eastern California, Eos Trans. AGU, 64, 336, 1983.

Benioff, H., and B. Gutenberg, The Mammoth "Earthquake Fault" and related features in Mono County, California, Bull. Seismol. Soc. Am., 29, 333-340, 1939.

Blackwell, D. D., A transient model of the geothermal system of the Long Valley caldera, California, J. Geophys. Res., 90, 11, 229-11, 241, 1985.

Blake, S., Volatile oversaturation during the evolution of silicic magma chambers as an eruption trigger, J. Geophys. Res., 89, 8237-8244, 1984.

Chouet, B., and B. R. Julian, Dynamics of an expanding fluid-filled crack, $J$. Geophys. Res., 90, 11,187-11,198, 1985.

Clark, S. P., Handbook of Physical Constants, Mem. Geol. Soc. Am. 97, 587 pp., 1966.

Delaney, P. T., and D. D. Pollard, Deformation of host rocks and flow of magma during growth of minette dikes and breccia-bearing intrusions near Ship Rock, New Mexico, U.S. Geol. Surv. Prof. Pap. 1202, 61 pp., 1981. Delaney, P. T., D. D. Pollard, J. I. Ziony, and E. H. McKee, Field relations between dikes and joints: Emplacement processes and paleostress analysis, J. Geophys. Res., 91, 4920-4938, 1986.

Eichelberger, J. C., P. C. Lysne, C. D. Miller, and L.W. Younker, Research drilling at Inyo Domes, California: 1984 results, Eos Trans. AGU, 66, 186$187,1985$.

Eyal, Y., and Z. Reches, Tectonic analysis of the Dead Sea Rift region since the Late Cretaceous based on mesostructures, Tectonics, 2, 167-185, 1983. Fink, J. H., Geometry of silicic dikes beneath the Inyo Domes, California, $J$ Geophys. Res., 90, 11,127-11,133, 1985.

Fink, J. H., and D. D. Pollard, Structural evidence for dikes beneath silicic domes, Medicine Lake Highland Volcano, Califomia, Geology, 11, 458 $461,1983$.

Gudmundsson A., Form and dimensions of dykes in eastern Iceland, Tectonophysics, 95, 295-307, 1983.

Hill, D. P., R. A. Bailey, and A. S. Ryall, Active tectonic and magmatic processes beneath Long Valley caldera, eastem California: An overview, J. Geophys. Res., 90, 11,111-11,120, 1985.

Jaeger, J. C., and N. W. G. Cook, Fundamentals of RockMechanics, 513 pp., Methuen, London, 1969.

Julian, B. R., and S. A. Sipkin, Earthquake processes in the Long Valley caldera area, California, J. Geophys. Res.,90, 11, 155-11, 169, 1985.

Kirby, S., Rheology of the lithosphere, Rev. Geophys., 21, 1458-1487, 1983. 
Lawn, B. R., and T. R. Wilshaw, Fracture of Brittle Solids, 204 pp., Cambridge University Press, New York, 1975.

Lide, C.S., and A.S. Ryall, Aftershock distribution related to the controversy regarding mechanisms of the May 1980, Mammoth Lakes, California, earthquakes, J. Geophys. Res., 90, 11, 151-11, 154, 1985.

Lynch, D. H., and P. Morgan, The tensile strength of the lithosphere and the localization of extension, Geol.J., in press, 1987.

Mastin, L. G., and D. D. Pollard, Surface deformation and shallow dike intrusion processes at Inyo Craters, Long Valley, CA, J. Geophys. Res., in press, 1988.

McGarr, A., and N. C. Gay, State of stress in the Earth's crust, Ann. Rev.Earth. Planet. Sci., 6, 405-436, 1978.

Miller, C. D., Holocene eruptions at the Inyo Volcanic chain, California-implications for possible eruptions in Long Valley Caldera, Geology, 13, 14-17, 1985.

Morgan, P. and M. P. Golombek, Factors controlling the phases and styles of extension in the northem Rio Grande Rift, Rio Grande Rift Field Conf. Guideb. N.M. Geol. Soc., 35, 13-19, 1984.

Naim, I. A., and J. W. Cole, Basalt dikes in the 1886 Tarawera Rift, New Zealand J. Geol. Geophys., 24, 585-592, 1981.

Pollard D. D., and O. H. Muller, The effect of gradient in regional stress and magma pressure on the form of sheet intrusions in cross section, J. Geophys. Res., 81, 975-984, 1976.

Pollard, D. D., O. H. Muller, and D. R. Dockstader, The form and growth of fingered sheet intrusions, Geol. Soc. Am. Bull., 86, 351-363, 1975.

Pollard, D. D., P. Segall, and P. T. Delaney, Formation and interpretation of dilatant echelon cracks, Geol. Soc. Am. Bull., 93, 1291-1303, 1982.

Priestly, K. F., J. N. Brune, and J. G. Anderson, Surface wave excitation and source mechanisms of the Mammoth Lakes earthquake sequence, J. Geophys. Res., 90, 11,177-11,185, 1985.

Sampson, D. E., Textural heterogeneities and vent area structures in the 600 year-old lavas of the Inyo volcanic chain, eastern California, The emplacement of silicic domes and lava flows, Geol.Soc. Am. Spec. Pap., 212, 89101, 1987.

Sampson, D. E., and K. L. Cameron, The geochemistry of the Inyo Volcanic chain: multiple magma systems in the Long Valley region, eastern California, J. Geophys. Res., 92, 10, 403-10, 421, 1987.

Savage, J. C., and R. S. Cockerham, Earthquake swarm in Long Valley caldera, California, January 1983, Evidence for dike inflation, J. Geophys. Res., 89, 8315-8324.

Secor, D. T., Role of fluid pressure in jointing,Am.J.Sci.,263, 633-646, 1965. Sorey, M. L., Evolution and present state of the hydrothermal system in Long Valley caldera, J. Geophys. Res., 90, 11, 219-11, 228, 1985.

Turcotte, D. L., and G. Schubert, Geodynamics--Applications of Continuum Physics to Geological Problems, 450 pp., John Wiley, New York, 1982.

Vogel, T. A., L. W. Younker, and B. C. Schuraytz, Constraints on magma ascent, emplacement, and eruption, Geochemical and mineralogical data from drill-core samples at Obsidian dome, Inyo chain, California, Geology, 15, 405-408, 1987.

Wallace, T. C., A reexamination of the moment tensor solutions of the 1980 Mammoth Lakes earthquakes, J.Geophys. Res., 90, 11, 171-11, 176, 1985. Weertman, J., Theory of water-filled crevasses in glaciers applied to vertical magma transport beneath oceanic ridges, J.Geophys.Res., 76, 1171-1183, 1971.

Weertman, J., and J. R. Weertman, High temperature creep of rock and mantle viscosity, Annu. Rev. Earth Space Planet. Sci., 3, 293-315, 1975.

Williams, H., and A. R. McBirney, Volcanology, 397 pp., Freeman, Cooper, San Francisco, 1979.

Wilson, C. J. N., A. M. Rogan, I. E. M. Smith, D. J. Northey, I. A. Naim, and B. F. Houghton, Caldera volcanoes of the Taupo Volcanic Zone, New Zealand, J. Geophys. Res., 89, 8463-8484, 1984.

Zoback, M. D., and J. H. Healy, Friction, faulting, and in-situ stress, Ann. Geophys., 2, 689-698, 1984.

Zoback, M. L., and M. D. Zoback, State of stress in the conteminous United States, J. Geophys. Res., 85, 6113-6156, 1980.

Zoback, M. L. and M. D. Zoback, Tectonic stress field of the continental United States, Geophysical Framework of the Continental United States, Geol. Soc. Am. Mem. in press, 1988.

J. Fink, Geology Department, Arizona State University, Tempe, AZ, 85287.

Z. Reches, Geology Department, Hebrew University, Jerusalem, Israel.

(Received December 29, 1986;

revised October 12, 1987;

accepted November 2,1987.) 